Andrews University

Digital Commons @ Andrews University

Master's Theses

Graduate Research

1967

\title{
A Pilot Study of Treatment Centers for Heroin Drug Addiction in New York City
}

Phyllis Somerville

Andrews University

Follow this and additional works at: https://digitalcommons.andrews.edu/theses

Part of the Counseling Commons, and the Education Commons

\section{Recommended Citation}

Somerville, Phyllis, "A Pilot Study of Treatment Centers for Heroin Drug Addiction in New York City" (1967). Master's Theses. 176.

https://dx.doi.org/10.32597/theses/176

https://digitalcommons.andrews.edu/theses/176

This Thesis is brought to you for free and open access by the Graduate Research at Digital Commons @ Andrews University. It has been accepted for inclusion in Master's Theses by an authorized administrator of Digital Commons@ Andrews University. For more information, please contact repository@andrews.edu. 


\author{
Andrews University \\ School of Graduate Studies
}

A PILOT STUDY OF TREATHENT CENTERS FOR

HEROIN DRUG ADDICTION IN NEW YORK CITY

A Graduate Project

Presented in Partial Fulfillment

for the Requirements of

the Master of Arts Degree

\author{
by \\ Phyllis Somerville \\ August, 1967
}

Approval:

M Dyen 



\section{TABIE OF CONTENTS}

Chapter

Page

I. INTRODUCTION...................... I

The Purpose of the study............. I I

Groups studied.................... I

Importance of the study.............. 3

Definition of Terms Used............. 6

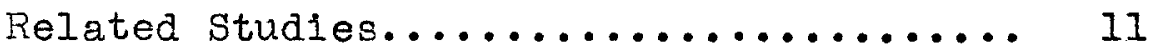

Sutherland's Theory.............. II

Description of Synanon Clients..... 12

Determination of Acceptance into

Synanon....................

14

Admission to Synanon............. 15

A Common Purpose................. I6

Group Cohesiveness.............. 18

Positive Attitudes Give Status...... 19

Service to Others.............. 20

Effectiveness of Program.......... 21

Organization of the study............ 23

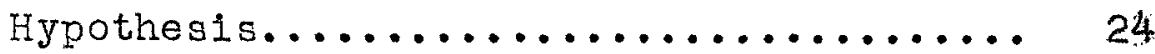

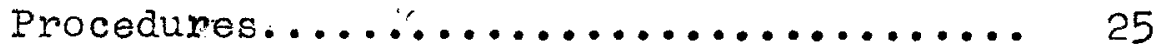

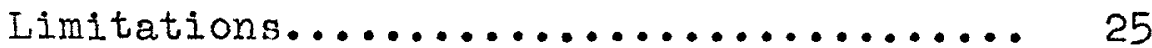


II. THE BRITISH METHOD OF CONTROL OF HEROIN.... 27 Proposal of Adoption of British Plan...... 28 Why the British Plan Would Be Unwise in the United States................ 30

III. HISTORY OF TREATMENT IN NEW YORK CITY..... 32

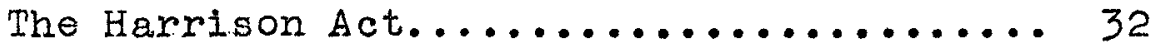

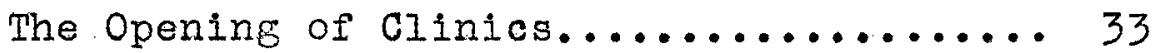

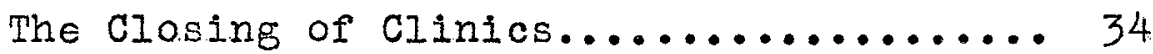

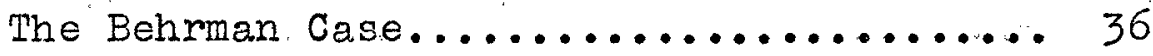
Opening of Two Federal Hospitals for .....

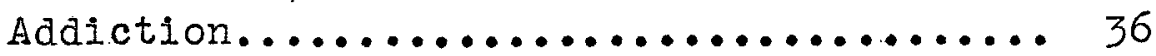
Ineffectiveness of Program Despite Many Services......................... 37 The New York City Penitentiary.......... 39 Bellevue Hospital.................. 40 Westside and Riverside Rehabilitation...... Centers........................... The Post Graduate Center of Psychotherapy. 41 The Hogan Silver Plan............... 42 The Methodone Program............... 42 Questions Raised as to Benefits........ 45 Cyclazocine Experiment.............. 47 Recent Legislation.................. 49 
IV. PERSONALITY AND FAMILY FACTORS........ 51

Introduction.................... 51

Attitudes Found in Potential Addicts.... 52 Comparative Study of Activities of Users

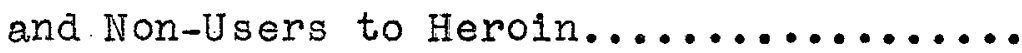

Physical Addiction Compared to Psycho-

logical Addiction................. 55

Personality Problems................ 56

Overt Schizophrenia.............. 56

Incipient Schizophrenia............ 57

Dominated Character Disorders......... 57

Pseudopsychopathic Délinquents......... 57

Oral Characteristics.............. 58

Inadequate Personalities............. 58

Ego Pathology..................... 58

Narcissism.......................... 64

Problems of Sexual Identification....... 65

Superego Pathology................ 72

Effects of Family Living on Child's Creativity.......................... 81

Attitudes Formed in Childhood........... 82

How the School Can Improve the Education. 85

Schools are Geared to Middle Class

Chilaren......................... 


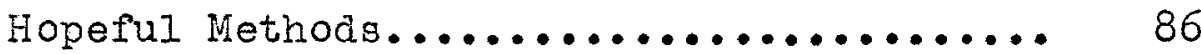

Stigma of Being Negro.................. 88

Susgested Improvements for Education of

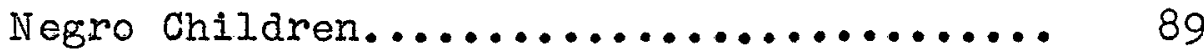

Higher Horizong Program................ 90

V. Treatment Centers Visited............... 91

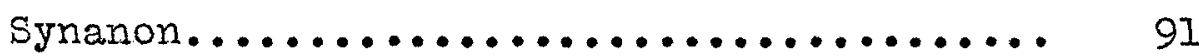

Location and History............. 91

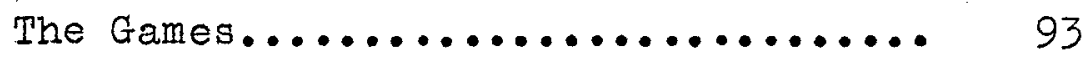

Synanon Therapeutic Methods......... 94

Synanon Philosophy............... 95

Synanon Prayer..................... 95

Success of Synanon Methods......... 96

Population of Synanon............. 99

No Use for Religion............... 99

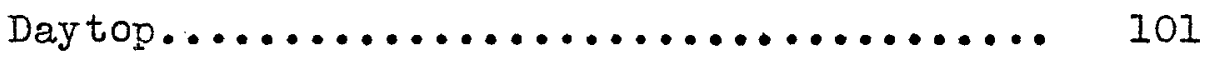

History and Location............... IOI

A three Phase Program............. 102

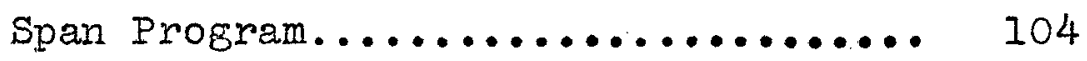

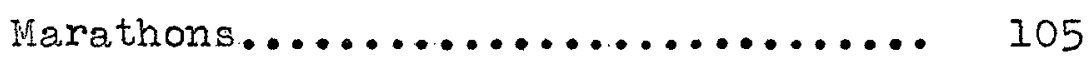

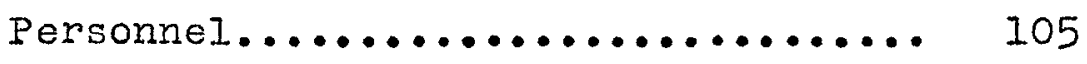

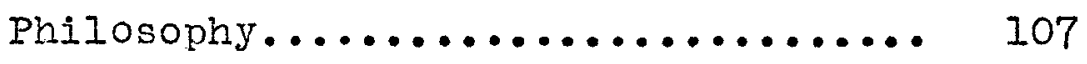

Initiating Treatment............ 112

Discussion Group Visited.......... 113 
Honesty Implanted................. 115

Family Living Teaches Responsibility..... 116

90 Day Hump.............................. 116

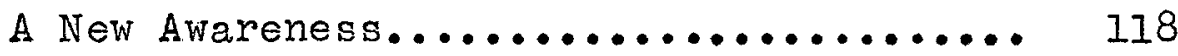

New Personality Emerging............. 119

Leisure Time....................... 120

Exodus House ...................... 121

Personnel......................... 121

Residence Quarters.................. 123

Voluntary Program.................... 124

Needs and Efficiency.................. 124

Vocational Rehabilitation.............. 124

Religion, Not Primarily Oriented....... 126

East Harlem Protestant Parish: Parent...

Organization..................... 126

Gree Haven Prison Program of Exodus

House........................ 127

Hart Island Community Center............ 130

Location and Personnel............... 130

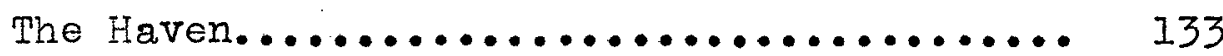

Dr. Robert w. Baird................. 133

The Treatment Program................ 135 
Christian Reformed Church............ 138

Personnel and Program............. 138

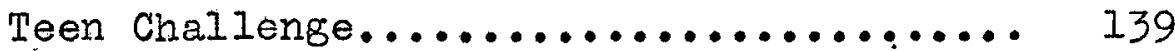

History of First Organization...... 139

Effectiveness of Program.......... 141

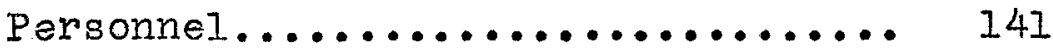

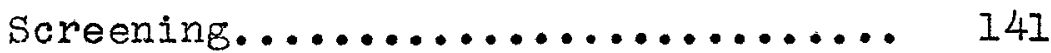

Religious Service Visited............ 147

Experiences of Youth................ 148

Power of Holy spirit Captures to

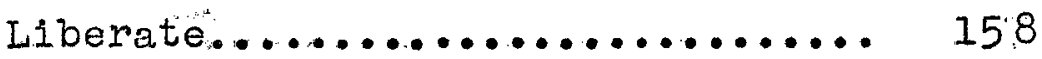

Physical Pilant................. 159

In1tial Treatment.............. 160

Sent to Training Camps........... 161

Damascus Christian Church........... 162

Personnel and Program............ 162

Faith for New BuildinB........... 164

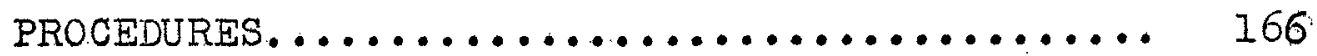

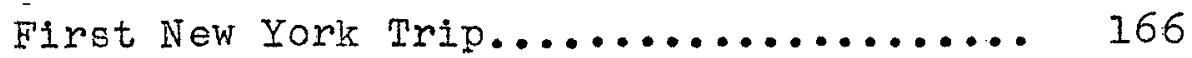

Second New York Trip................ 173

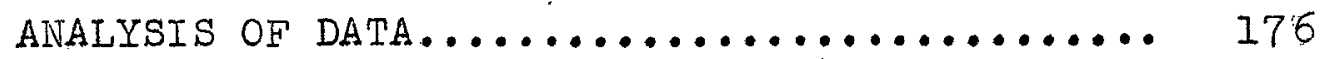

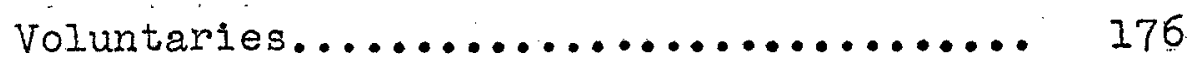

Residence Programs.................. 177 


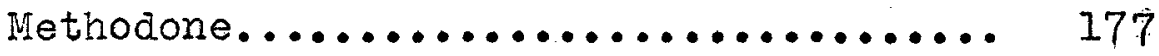

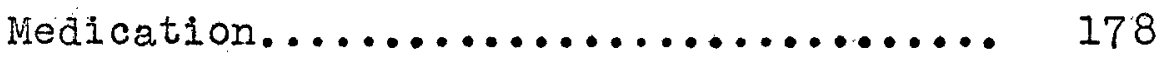

Group Counseling................. 178

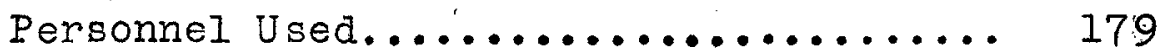

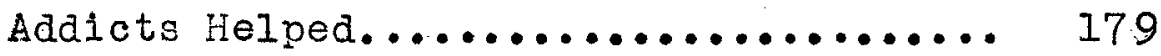

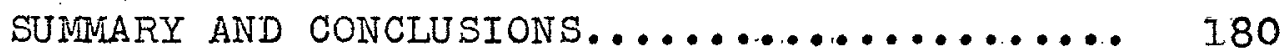

Helpful Book for Ministers........... 18I

Adventists Question Tongues as Evidence

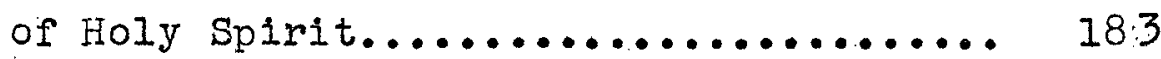

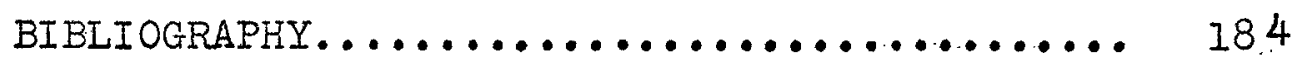

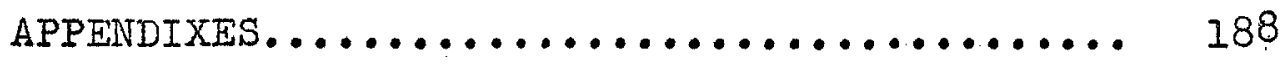



CHAPTER ONE

INTRODUCTION

The Purpose of the Study

The purpose of the study is to survey methods used by some groups and institutions listed below who are attempting to cure heroin drug adaiction. In this study an attempt has been made to discover which method, technique or combination of methods and techniques are most effective for permanent cure. Also 1t will outline the past history of treatment used in New York C1ty and give a brief proposal of its new treatment program as of Apri1 1, 1967.

The study will seek to evaluate the counseling techniques used as. well as other supportive theraputic methods. It will also seek to point out how a strong evangelical approach can be used effectively with other useful methods being used by secular groups. It is to show that this emphasis is the most effective and an all around program.

\section{Groups Studied}

The following are a list of the groups or institutions included in the study. This is by no means an ex- 
haustive list of those organizations or persons helping to cure drug addition in New York City. Unofficially it was stated to the writer by a member of Synanon, Mr. Ben Depoacito on July 8, 1967, that there were approximately a hundred such individuals or groups doing such work. In a letter dated June 21, 1967 from Mr. Dominick M. D1Giola, R.Ph., Information Officer of the office of the Coordinator of Addiction Programs for the City of New York that a list is in process of formation.

1. Christian Reformed Church of Manhattan, 2042.7th Avenue, New York City. Rev. James Allen and Gordon Negan are in charge.

2. Damascus Christian Church, 931 East 162nd Street, New York City. Rev. Leone Roussequ is in charge of the program.

3. Daytop, 450 Bayview Avenue, Staten Island, New York, New York. Dr. Daniel Casriel is the medical superintendent and Mr. David Deitch is the Executive Director.

4. Exodus House, at one time connected with East Harlem Protestant Parish 1s Iocated at 306 East 103 rd Street, New York City. Rev. Steven Chinlund and Rev. Lynn Hagmen are in charge.

5. Hart Island Community Center on Hart Island off City Island, Bronx, New York is one of the New 
Yoris City facilities opened in May, 1967. It is under contract of the New York State Narcotic Addiction Control Commission.

6. The Haven, is located at 222 East 116th Street, New York City. This is privately operated by Dr. Robert w. Baird after hours of his regular practice.

7. Synanon is located at 35 Riverside Drive, New Yoris, as a headquarters office of the national program of Synanon.

8. Teen Challenge is located at $444^{\circ}$ clinton Avenue, Brooklyn, New York. Rev. David Wilkerson is the founder while his brother, Mr. Don Hilkerson is the director of the program in New York City. Rev. Wilkerson is an Assembly of God minister.

The Importance of the Study

From the office of Dr. Efren Ramirez, Coordinator of Addiction Programs in New York City, it is reported that in this city, one out of every elghty persons is a drug addict: This figure is $90 \%$ of the addict population of the state of New York. It is $50 \%$ of the population of addicts of the whole United States. In the city of New York, each addict is the means of bringing in four or five more addicts into existence. I In 1965, New York City

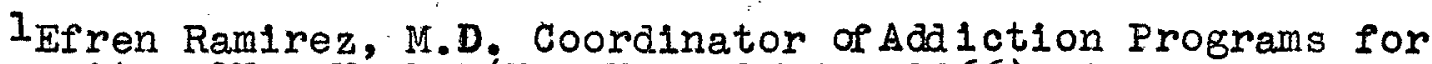
the city of New York, (New York, October 1966) mimeographed p.1. 
had 13,877 narcotic arrests. 1

In personal conversation with Mr. Dominick DiGiola of the Office of Coordination of Addiction Programs of the City of New York as 1ts Information Officer, the writer was told on June 8, 1967 that a conservative estimate of the number of addicts in New York C1ty would be 100,000. No distinction was given as to the type of drug used, but heroin is the biggest problem. No one actually knows how many more there may be as these figures are only compiled from lists of arrests or of persons who come voluntarily to places for treatment.

"Narcotic addicts are estimated to be responsible for one half the crime committed in the city of New York alone and the problem of narcotic addiction is rapidiy spreading into the suburbs and other parts of the state. The threat to the peace and safety of the inhabitants of the state must be met. Not only crime, but unemployment, poverty, loss of human dignity and of the ability to fill a meaningful and productive role in the community, as well as damage to the physical and mental health of the addict himself are all by-products of this spreading disease. The narcotic adict needs help before he is compelled to resort to crime to support his habit. The

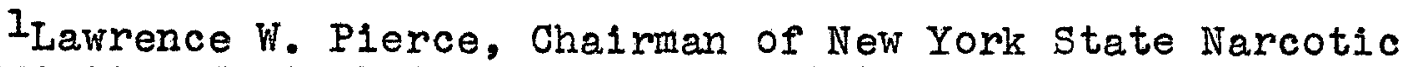
Addiction Control Commission, The Attack on Narcotics, (Albany, New York), p.I. 
narcotic addict who commits a crime needs help to break his addiction. A comprehensive program of treatment, rehabilitation and aftercare for narcotic addicts can fill these needs. I"

It may be too early to know if the addict will never retum to his habit, nor is it reasonable to think that any institution could possibly keep a life history on a former patient to know if he stayed that way the rest of his life. But some institutiong with several years experience who have done their best to keep in contact with former clients can give us some idea of the effectiveness or ineffectiveness of their programs.

\section{Programs with an Evangelical Christian Emphasis}

It is believed that an evangelical emphasis which points the adict to Jesus as Savior over every temptation, drug addiction being only symptomatic of an alienation from Christ, it is the most effective means of curing addiction. This experience of salvation, with direct counseling as to how to live the Christian life, along with Bible instruction has proven very effective.

It is not the purpose of this paper to criticise what is being done by other groups, as understandably

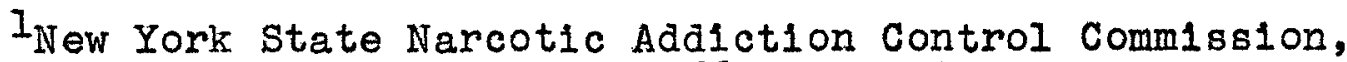
Chapter 192 of the Laws of 1966, p. 1-14. 
state programs cannot enter into religlous instruction. Other organizations, not holding to the Christian philosophy as an answer to this problem in the same intensity as do the strictly evangelical groups, nevertheless have Christian principles which they are instilling in the minds of their clients, as also are the city programs. It cannot be said that only the evangelical groups ascribe to Christian ideals. But it can be said they are representative of those who belleve that the power of prayer can change an addicted person, giving him new direction to his Iife in the matter of moments. In the long-term rehabilitation, evengelical groups use a Bible centered approach, whereby other groups stress such principles as honesty, love, and trustworthiness, but do not go directIy to the writings of the Bible for their reference, but to secular writers or to their own personal experiences. The secular programs have many good features which the religious groups are also fostering by way of work programs of rehabilitation. Secular groups seem to lack the ingredient of faith for a person to be cured or to stay cured. This "ingredient" is the power of the Holy Splrit in the life to empower the person to overcome temptation.

Definition of Terms

1. Drup Addiction. This is a state of periodic and 
chronic intoxications detrimental to the individual and to society, produced by the repeated consumption of a arug (natural or synthetic). Its characteristics include: an overpowering destre or need (compulsion) to continue taking a drug and to obtain it by means illegal; a tendency to increase the doses; a psychic (psychological) and sometimes a physical dependency on the effects of the drug. I This definition is from the World Health Organization as quoted in the reference below.

2. Cold Turkey. This term means going off drugs when no drug, either the same in lesser amounts, or a substitute drug is given. This method was explained by Mrs. Robert W. Baird, receptionist and wife of Dr. Robert W. Baird, who operates "The Haven".

3. Detoxification program. This is a means of gradually getting an adict off heroin. On the first day he is given 45 milligrems of herolnoper day or 15 milligrams, three times a day. On the second day, he is reduced to 30 milligrams periday, or ten, three times a day. On the next day, he is given 15 milligrams of heroin per day, or 5 m1lligrams three times a day. When he is down to five, twice a day, and then to only 5 milligrams once a day he feels no more physical need for

IAlfred R. Lindesmith, Drug Addiction; Crime or Disease?, (Bloomington, Indiana, Indiana University Press, 1961), p. 23. 
the drug. He is only a little weak. This program was explained by a former addict who had gone through this program, whose name the writer falled to get. This is the program of several large hospitals, including Manhatten General Hospital in one section of the hospital. 4. Methodone program. This is a method used at another "station" at Manhattan General Hospital of giving a substitute drug instead of heroin. This drug. known since the Second World War, and discovered in Germany for a pain reliever was found by Dr. Marie Nyswander and her husband, Dr. Vincent P. Dole to take the urge for heroin away. It is administered orally and also intravenously each day at the hospital. The patient stays at the hospital at first for the intravenous injections and later as an outpatient gets it orally in orange juice. The writer received this information by phone from the Manhattan Hospital.

5. The Narcotic Addiction Control Commission.

"This commission of the state of New York was established by that state within the department of mental hyglene to formulate plans for law enforcement and treatment of addiction. It shall consist of five members appointed by the governor with the advice of the senate. Insofar as practicable, the members of the Commission shall possess broad knowledge and experience in medicine, psychology, 
social work, sociology, education or law. They are salaried and full time workers serving a five-year term. The members first appointed shall serve for terms of one, two, three, four and five years, respectively."I

6. The Council on Drug Addiction of New York State. "The Council is an advisory body with no executive or appointive powers. The Council is advisatory to the Commission ( $r \in f \in r r e d$ to above) upon the formation of a domprehensive plan for long range development through the utilization of federal, state, local and private resources of adequate services and facilities for the prevention and control of drug addiction, diagnosis, treatment and control of drug addicts and the revision from time to time of such plan. Also, it is to advise in promotion, development, establishment, coordination and conduct of unified programs for education, prevention, diagnosis, treatment, rehabilitation and control in the field of drug addiction in cooperation with other federal, state, local, and private acencies. The members are not paid as such as they are already on salary from their various departments. Those on the Council are the commissioners of mental hygiene, the chaiman of the board of parole, the director of the division for

$$
\text { I I 1d., p. } 3 \text {. }
$$


youth, the chairman of the commission, and the mayor of the city of New York or his duly designated representative, each to serve as permanent ex-officio members to be appointed by the governor from outside state government."I

6. Coordinator of Addiction Programs. This coordinator is appointed by the governor as chairman of the Commission and is the chief executive officer. Dr. Efren Ramirez at 250 Broadway, 14th Floor, New York, New York, 10007 is currently in this position. 2

7. Kicking the habit. This expression means to be rid of the habit of drug addiction.

8. Clean. This means to stay off of drugs. A person may refer to being clean for a certain period of time as so many days.

9. Drilling. This slang expression means using the hypodermic needle for giving a shot of heroin. 10. Contact. This means finding a person who will either sell or give a drug to an addict.

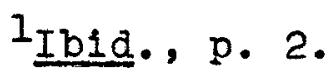

${ }^{2}$ Ib1a., p. 4. 
Related Studies

A Synanon Study

Synanon is the name of several treatment centers originating in San Monica, Califomia. This center w1ll be referred to later in the paper. Sutherland's Theory

In 1955 Donald R. Cressey, Dean of the University of California listed five principles for applying Edwin Sutherland's theory of differential association to the rehabilitation of criminals. 1 This article is now frequently cited as dealing with "group therapy," "therepeutic communities," and "total institutions." But it is not known that any such community is based upon these theories. The major point of Cressey's article referring to criminals, not addicts is similar to the recommendation of the Chief of the United States Narcotic Division. "The community should restore the former addict to his proper place in society and help him avold associations that would influence him to return to the use of drugs. "2:

To test these principles, Rita Volkman working on

IDonald R. Cressey, "Changing Criminals: The Application of the Theory of Differential Association, "American Journal of Soclology, LXI, September, 1955, p. 116-20.

2 Harry J. Anslinger, "Drug Addiction", Encyclopedia Britanica, VII, 1960, pp. 699-79. 
a research paper for her Master's degree in the Department of Education of the University of California went to Synanon in Santa Monica, California as a non-addict member. She visited the group daily and lived there on week-ends from December, 1958 until JuIy 1959. Then she moved in to the bigger quarters synanon then had as a full time member until June, 1960. At her invitation, Dean Cressey was invited to visit and beginning July, 1960, he visited the group. They deliberately refrained from trying to influence the policy there. Cressey's theories were unknown to the group. Most of the statistical and interview material was gathered by Miss Volkman, who wrote," A Descriptive Case Study of Synanon as a Primary Group Organization." This is an unpublished manuscript. 1

Description of Synanon Clients

Miss Volkman studied the first fifty-two persons who entered Synanon after July, 1958. The median age of residents for men was 31.0 and for females 27.5 . It is believed that these are representative of the 215 persons who have resided at synanon for at least one month. 2

IJohn A O'Donnell and John C. Ball, Narcotic Addiction, (New York, Harper and Row, 1966), p. 211.

${ }^{2}$ Ibid., p. 211 . 
There were 35\% Catholics, $44 \%$ Protestants, and 8\% Jewish. By May 1961 the Jewlsh population had increased to $20 \%$. Raclally, $27 \%$ were Negroes, no Orientals, $19 \%$ of the Caucasians were of Mexican origin and $13 \%$ were of Italian origin.I

Educationally, 2\% had only part of grade school completed, $6 \%$ had completed grade school, $46 \%$ had completed part of high school, $21 \%$ had graduated from high school, and $25 \%$ had part of college, but there were no college graduates. 2

As for work experience, $67 \%$ had defined their work as "for short periods only." To support their addiction which cost from $\$ 30$ to $\$ 50$ and sometimes $\$ 100$ a day, only four men reported that they had done it legitimately by work alone. Armed robbery, shoplifting, theft, and butglary, as well as pimping was reported by $79 \%$ as their way to raise funds for heroin. One man and seven women had been supplied by their families or mates. Five women used prostitution or other illegitimate work. Five of the fourteen women had no income other than illegitimate means and none of the women supported themselves by legitimate work alone. 3

$$
\begin{aligned}
& \text { I Ibid., p. 211-12. } \\
& \text { I Ib1d., p. 211-12. } \\
& \text { I Ibid., p. 212-213. }
\end{aligned}
$$




\section{Determination of Acceptance into Synanon}

These fifty-two members, according to military

and prison records were not "easy" rehabilitation cases.

Total confinements to prison were 166 for the men's group, and 59 for the 14 women. This makes an average number of jail confinements for males as 5.5 times, and women 3.9 times. ${ }^{I}$

No one is accepted to synanon without having to convince the staff that they mean business. Cressey's first principle shows that synanon is using this approach. 2

If criminals are to be changed, they must be assimilated into groups which emphasize values conducive to law-ablding behavior and, concurrently, alienated from groups emphasizing values conducive to criminality. Since our experience has been that the majority of criminals experience great difficulty in securing intimate contacts in the ordinary groups, special groups whose major common goal is for the reformation of criminals must be created. 3

This assimilation into a culture free from arugs is achieved in the Synanon program. Strict rules apply as to contacts with the old world of drugs.

When a person applies to come to synanon he is given what is known as a "dressing down" as the leaders of syn-

$I_{\text {Ibid.. p. } 213 .}$

2 ${ }_{\text {Ibid., p. } 214 .}$

3 Ibid., p. 214. 
anon figure the addict is a psychopathic liar. "It's all in the attitude. It's got to be positive. We don't want their money. But we may just tell him to bring beck some dough next week. If he pleads and begs, the money's not important. If he shows he really cares. If his attitude is good. It's all in the attitude... Sometimes we yell at him and tell him he's a liar. If he's serioud he'll take it. He'll do anything if he's serious."I Admission to Synanon

"The admission process is important for it gets the person to admit he's willing to conform to the norms of the group, whose members will not tolerate any liking for drugs or drug addicts. From the minute the addict enters the door, his expressed desire to join the group is tested by giving him difficult orders-to have his hair cut off, to glve up all his money, to sever all family ties, to come back in ten days or even thirty days. He is told explicitly the difference from the good and the bad guys--the bad shoot dope. Second, the admission process weeds out those who just want a free bed and food or to stay away from the police. He must want to give up arug addiction, not just the drug habit, as distinguished by Lindesmith. This means

$$
1_{\text {Ibid., p. } 214 .}
$$


he must at least say he wants to stay off drugs once and for all, in order to realize his potential as an adult; he must not indicate he merely wants a convenient place in which to go through withdrawal distress so that he can be rid of his habit for a short time because he has lost his connection, or for some other reason. He must be willing to give up all ambitions, desires, and social interactions that might prevent the group from assimilating him completely."I

No addict has been refused admittance because he looked like a tough case to rehabilitate. Twenty-nine of the fifty-two members of synanon at the time of the study had been on drugs at least ten years. Two of those had been addicts for forty years and been in and out of institutions during that time. The average length of time of addiction had been eleven years, and $56 \%$ reported a month as the longest time of refraining from arugs. 2

\section{A Common Purpose}

The more relevant the common purpose of the group to the reformation of criminals, the greater will be its influence on the criminal members attitudes and values. Just as a labor union exerts strong influence over

I Ibid., p. 215.

IIbid., p. 216. 
its members'attitude toward management, but less influence over 1ts members' attitudes toward, say, Negroes, so a group organized for recreation or welfare purposes will have less success in influencing criminalistic attitudes and values than will one whose explicit purpose is to change criminals. 1

Synanon continually stresses that this is a druglegs, alcohol free and crimeless group. The addict is reminded a dozen times a day that if he wants to stay at synanon, he must stay clean of drugs. 2 The addict is allowed no phone calls or letters from the outside for some time. Letters will be read before the group. The person is asked never to be alone at first during withdrawal. If he takes a walk, he must ask permission and then go with a member who can be trusted. "No need to act worried about your family," they are told, "you didn't before. All you know how to do is shoot dope. Forget it." If they don't like the program they are told to "get lost." Doors are not locked from the inside, only on the outside for protection. 3

All street talk is taboo as it is about the past Iife of addiction. Here they are taught that the accepted thing is to squeal on someone who disobeys. On

\footnotetext{
${ }^{1}$ Cressey, p. 20-26.

20'Donnel1, op. cit., p. 216.

I Ibia., p. 217.
} 
the street it was the opposite. If he associates with an addict he is given a verbal dressing down which 18 really Magnified. Then he must apologize to the whole group. He loses rank in the steps of progress in his work program. $\mathrm{He}$ is given the lowest jobs first, but can climb according to the number of days he has stayed clean. 1

\section{Group Cohesiveness: Cressey's Third Principle}

The more cohesive the group, the greater the members readiness to influence others and the more relevant the problem of conformity to group norms. The criminals who are to be reformed and the persons expected to effect the change must, then, have a strong sense of belonging to one group; between them there must be a genuine "we" feeling. The reformers, consequently, should not be identifiable as correction workers, probation or parole officers, or social workers.?

The da1ly program is designed to put the members together as working in a family unit and all but the third stage level live as a family. "Be yourself," it is urged." Speak the truth. If someone does not like what someone has said or done he can feel free to air it in a group which meets twice a day or at any other time if necessary. Holidays and birthdays are celebrated. To some it is the only home they have known.

IIbid., p. 218.

2 cressey, op. c1t. p. 20-26. 
Relevant to Cressey's princlple, the resident can leave at any time.

Also the strong factor that "we were all just like you" comes to play as when a new member comes and must withdraw from the drug out in the open on a couch. He is not put in isolation, but life goes on as usual with the subleness of the suggestions other members leave with him, "we did 1t; so can you." This has much more effect on him than if a person who had never experienced addiction were to say this. 2

Positive Attitudes Give Status: Cressey's Fourth Principle

Both reformers and those to be reformed must achieve status within the group by exhibition of "pro-reform" or anti-criminal values and behavior patterns. As a novitiate...he is a therapeutic parasite and not actualiy a member until he accepts the group's own system for assigning status. 3

This is the crucial point to Cressey's formula and the one upon which Synanon seems most effective. Here the person is given status by the number of days off drugs. He may eventually be part of the staff. To be a Senior Coordinator, the member must be free of drugs, crime, or alcohol for at least six months. He

I Cressey, op. cit.

20'Donnel1, op. cit., p. 227-230.

3 Cressey, op. cit. 
must also show that he can leave drugs alone in situations where he could have gotten drugs. So his attitudes must be right, no matter what his skills are. Evaluation is casual, but it is effective to see if he is truthful, expresses emotions freely, cooperates in sroup activities and demonstrates leadership abilities. 1

Service to Others: Cressey's Fifth Principle

The most effective mechanism for exerting group pressure on members will be found. in groups so organized that criminals are induced to join with noncriminals for the purpose of changing other criminals.?

One is expected to tell the truth as well as insist upon the truth. An example was given of cross examination of one of the members by another who tried to fake that she was calling the doctor regarding her weight after having a baby. She was really calling her husband as she wanted to go home, but finally in the end recognized the fact that she was not ready to go home yet and unless she cut loose from family awhile she would be there the rest of her life. It took quite a lot of probing to get the whole truths out of her as the inquirer at first accused her of trying to con the doctor into giving her drugs. 3

I.'Donne1I, p. 227-230.

$2_{\text {Ibid. , p. } 231 .}$

I Ib1a., p.232. 
"Of the fifty-two residents described earlier, four are 'graduates' of Synanon, living in the community, and are not using drugs or alcohol. Twenty-three (44\%) are still in residence and are not using drugs or alcohol. Two of these are on the Board of Directors and eleven are working part or full time off the premises. The remaining twenty-five members left at Syaanon's disapproval. I Effectiveness of the Progrem

"Between May, 1958, when Synanon started, and May 1961; 263 persons were admitted or readmitted to synanon. of these 190 or $72 \%$ left synanon agalnst the advice of the Board of Directors of the older members. But $59 \%$ of all the dropouts occurred within the first month of residence, $90 \%$ within the first three months. Synanon is not adverse to giving a person a second chance, or even third or fourth. Of the 190 persons aropping out, $44 \%$. were persons who had been readmitted. 2

"Of all the Synanon enrollees up to August, 1962, 108 out of $372(29 \%)$ are known to be off arugs. More significantly, of the 215 persons who have remained at Synanon for at least a month, 103 (48\%) are still off drugs. Of the 143 who have remained for at least three months, $95(66 \%)$ are still non-users. Those staying for

$$
\begin{aligned}
& I_{\text {Ibid., p. }} 231 . \\
& \text { I Ibid., p. } 232 . .
\end{aligned}
$$


seven months were 87 and of this number 75 or $86 \%$ are non-users. This shows that once an addict becomes a member of the group from 3-6 months, the probability that he wiIl leave and return to arugs is low. 1

A Twelve-Year Follow-Up of New York Narcotic Adalcts: The Relation of Treatment to Outcome

"A group of 100 male New York City addicts admitted to the United States Public Health Hospital at Lexington, Kentucky, between August 1952 and January 1953 were followed for twelve years or 1965. N1netyfour percent were successfully followed for at least ten years; $75 \%$ of the patients were volunteers. The majority of the patients had begun the illegal use of drugs in late adolescence and had been considered antisocial although they were not imprisoned prior to Lexington, and after Lexington $90 \%$ received jail sentences. Nevertheless, at time of last contact, $46 \%$ of the sample were off drugs and in the community. Thirty percent had been abstinent for at least three to twelve years."2

${ }^{1}$ Ibid., p. 231

2 George E. Vaillant, M.D., "A Twelve-Year Follow-Up. of New York Narcotic Addicts: The Relation of Treatment to Outcome." The American Journal of Psychiatry, Vol. 122, No. 7 , January 1966. 
The length of short term abstinence after Lexington appeared to be correlated with the length of hospitalization. More dramatic, however, were the findings that $96 \%$ of all addicts who sought voluntary hospitalization for their addiction relapsed within a year and that $67 \%$ of those who received at least nine months of imprisonment and a year of parole were abstinent for a year or more. The most significant variable in determining abstinence in the confirmed addict appeared to be the presence or absence of constructive but enforced compulgory supervision. The writer believes that both prison sentences without provision for parole and purely voluntary programs are often contraindicated in the treatment of urban addiction."I

\section{Organization of the Study}

Chapter I has been designed to identify the problem of heroin addiction and to name some groups studied, 10cation of centers and of those in charge of the group. It gives the importance of the study. A list of terms are defined. This chapter deals with two related studies. A hypothesis is given this study is aimed to test.

Chapter II is a study of the British system and the reasons given why it could not be effective in the United States.

$i_{\text {Ibid. }}$ p. 736. 
Chapter III gives the history of treatment centers and planning in New York City from the Harrison Act in 1914 to the most current happenings as the opening of the Hart Island Community Center in mid-May, 1967.

Chapter IV deals with the personality factors and the home backgrounds which make a person more prone to drug addiction.

Chapter $V$ deals with how the school can Improve the education to make a less drug prone culture.

Chapter VI deals with the various treatment centers: Synanon, Daytop, Exodus House and Green Haven Prison, Hart Island Community Center, The Haven, Chrlstian Reformed Church of Manhattan, Teen Challenge, and Damascus Christian Church.

Chapter VII deals with the procedures and sources of data.

Chapter VIII is an analysis of the data found in the study.

Chapter IX is a summary and conclusions of the study.

The Bibliography follows with the Appendices which contains a questionnaire, the only instrument used. Hypothesis

The drug addict's answer to his problems is God. This relationship means personal salvation and the help of the Holy Splrit to give him power to live a drug free 
Iife.

\section{Procedures}

The writer became aware of several treatment centers in New York City by reading magazine articles or books before making a trip to New York City on June 6,7, and $8 \mathrm{th}, 1967$. Here other places were named by those working with addicts. The writer endeavored to visit those places, but for the lack of time was not able to get them all seen or at the depth desired. A return trip was made July 6,7 , and 8 th, of the same year. The centers listed in the study were all visited except two and phone calls were make. One not visited was Exodus House and the other, The Haven as the doctor was out of town. Part of the "In depth" was accomplished but limited again by time.

Wide reading has also been done in the area of adalction as well as conversations with those working with addict treatment enhanced the study. Some conversations were also with addicts.

\section{Limitations}

The writer was limited in time as much more could have been done in talking to the exact personnel who performed a certain service, rather than getting the information the only way of the moment as through a secretary. Key persons are busy and the writer did not feel it right to take them from their all important duties 
of treating addicts. The writer wished to be allowed to visit a session of group therapy which was beginning at the very time of the visit, but their space was limited and it was not possible. A crowd was at the Christian Reformed Church of Manhettan, which made it unwise for Its administrator to welcome the writer to visit as they were rushed. The phone call was even shifted to a second representative. Teen Challenge does not allow visitors to see the dormatories where new addicts live when they are kicking the habit and are recelving spiritual counseling. The writer would also have liked to have seen some addicts at the Damascus Christian Church, but none were on hand. Nor was their leader, Rev. Leone Rousseau present. It would have been most enlightening to have been able to have visited the farm camp programs of both these strongly evangelical centers, but of course they were distant. 
CHAPTER TWO

THE BRITISH METHOD OF CONTROL OF HEROIN

Controversial Issue

There has not been much success in the past in the treatment of addiction. To date, according to Johnson, there are not proven effective methods of drug adiction cure applicable to the total addict population. In 1929 the National Hygiene Council accepted a grant from the Bureau of social Hygiene Incorporated to conduct research into the cause, effect, prevention and cure of drug addiction, but nothing was accomplished which was beneficial in telling how to cure dmg addiction to heroin. It merely studied the chemistry of various addiction drugs. 1

There has been much controversy over the British system of legalizing arugs, dispensed to the adaict through a doctor. Some feel we are making problems because the pushers do so well financially in that 11legal drugs make the price high. They would be disinterested in the racket if there were not the tremendous

IJohn Kobler, "Britains RX for Our Drug Addicts," Saturday Evenins Post, July, 1966., p. 74. 
profit involved. The government pays the doctor the equavalency of a dollar per patient a year. The addict pay.s only twenty shillings or twenty-elght cents a shot. Here he may spend $\$ 30$ per shot. Both sides of the Atlantic are looking with scrutiny on this plan. Britain does not have the enormity of problems as we in America. The doctor is supposed to be curing the addict, not just satisfying his gratification, but this poses a dilema.l An already harassed doctor has to see a junkie as many as a hundred and ten times, as reported for one junkie. Even this has given the patient drugs for home "fixes." It is appearing that addiction has reached the thousands and not just the hundreds as the Home Office would like to claim. Americans are finding 1t convenient to move to Britain for cheap arugs.? Proposals for Adoption of British Plan

Some bills are up before the United States Congress which would bring our narcotics laws closer to those of Britain's. The catch to the British system is that it is keeping addicts supplied with a comfortable supply of drugs all their lives. Their law is essentially the

I Ibia., p. 74 .

2Davia P. Ausubel, "Controversial Issues in the Management of Drug Addiction: Legalization, Ambulatory Treatment, and the British System," John A O'Donnell, op. cit. p. 205-208. 
same as ours in that drug addiction is not a crime, but the 11 legal possession of drugs is and the physicians are not to prescribe the drugs except with the thoughts of withdrawal or apart from witharawal, therapy, if it is felt the therapy medically dangerous! The Dangerous Drug Act of 1920 is presently interpreted so that narcotics may be legally administered to addicts by physicians legally to supply addicts with enough narcotics to gratify their euphoric needs, since the authorities demand no proof that the addict in question is leading a normal and useful life, or that the drug is essential and is given in the minimum dose necessary for this purpose. The deliberate ambiguity of this legalistic dodge kills many birds with a single stone; British addicts are kept happy and out of mischief; the 1llicit market in drugs is undermined; the government has an inexpensive way of handing and keeping track of the addiction population; physicians receive a government subsidy for writing narcotic prescriptions; and above all, the government is able to maintain the legal fiction that drug addiction if officially prescribed and can thereby live up to its international commitments in this regard."I

I Ibid., p. 205-208. 
Why the British Plan Would be Unwise in the United States

"Although this practice is the epitome of amoral expediency, it apparently has not led to widespread addiction when though the figure of 359 addicts in the entire British Isles is too small to be credible (so reports the Home Office). The high per capita consumption of legal narcotics suggests the existence of much masked addiction. The British are able to get away with this system without creating an army of new drug adicts because the existing rate of drug addiction is low and there are many fewer potential addicts than in the United States. Since drug addicts are generally able to obtain legally as high a dosage as they desire and since the number of potential customers is too small to justify the risks involved, the illicit traffic is held to a minimum. Because of the much greater number of active and potential addicts in the United States, however, the adoption of the British system would soon create a half million new addicts without eradicating the illicit market."I

There is no comparison of the two countries or of any other European country and the United States. It can be apoculated that the smaller divorce rate, al-

I Ibid., p. 205-208. 
coholism, and major crime rates show Britain and other European countries to be a much more stable culture than the United states. Britain does not have the large unassimilated and underprivileged racially minority groups living under slum-urban conditions. Only $0.2 \%$ of the population of the United Kingdom 1s of non-Caucasian stock as compared to $16 \%$ of the American population. The significance of this difference lies in the fact that two-thirds of the addict population of the United States is from the later $16 \%$. So it might be said the lower rate in Britain exists despite the legalization and not because of it. If the method were tried where the country is more vulnerable to drug addiction as in the United States, it would only greatly increase addiction rates. Hong Kong, a British Crown colony has in 1957 a rate of $22 \%$ higher than that of the United States. This was 13,000 addicts in one city. ${ }^{1}$

$I_{\text {Ibid., p. 205-208. }}$ 


\section{CHAPTER THREE}

A HISTORY OF TREATMENT IN THE CITY OF NEW YORK

\section{The Harrison Plan}

First attempts to control drugs in the United States was passage of the Harrison Act in 1914. It was In the guise of an excise tax on various narcotics. The Act has succeeded in controlling the flow of legitimate arugs to doctors, but the traffic in smuggled arugs remains-the major problem. I Every attempt is being made to check ships and planes entering our ports of entry, as heroin is not legally manufactured in this country. This is almost impossible for it is so easily hidden. 2 Since it is illegal to have heroin, the price is kept high, and the incentive great for taking a risk at being caught. A few years in jall and the pusher is out again to continue his work. The Act makes it illegal to sell

1 Elmer Herbert Johnson, Crime, Correction and Society, (Homewood, Illinois, Dorsey Press, 1964.) p. 229.

2 "Narcotic Addiction: Official Actions of the American Medical Association," 1963, pp. 2-8. The selection.s from a "Report of Narcotic Addiction by the Council on Mental Health of the AMA, adopted by the AMA House of Delegates, June 1957. 
or to have narcotics in one's possession thus really making the addict a criminal rather than a sick person. He is a criminal for the fact he has the drug. This thinking of him as a criminal rather than a sick person needing treatment may be one reason for unsuccessful cure in the past. Opening of the Clinics

Prior to 1919, physicians prescribed drugs to addicts. However, a Supreme Court Decision made it illegal for physicians to do this for the purpose of gratifying the addict as there was abuse of this practice. Then after this decision many addicts in some states and municipalities appealed to their various Boards of Health for relief. Some clinics were then established at the suggestion of the Treasury Department in fortyfour cities. Some operated only for a few weeks and some for as long as four years. The clinics were only for the purpose of keeping the addict from exploitation of the drus peddler. The directors of some clinics admitted they were not attempting any cure. But then because of the nature of how often an adalct feels he needs his drug, it became impossible for the clinic to administer the drugs and the addict administered his own drugs. This caused abuse. Many doctors were being paid well to write the prescriptions. Staffs were small 
and facilities meager.1

"An exception to this rule occurred in New York City. Since there was not such a panic as was anticipated to get drugs when the law was changed, then the clinic altered 1 ts purpose to bring the addict into the open, furnishing him with drugs, but reducing the amounts that he might start rehabilitation and find employment. The drug was reduced preparatory to hospitalization in the institution operated on North Brothers Island, New York City. Seventeen hundred of the 7,400 addicts who registered in the New York City Clinic finally went to the island for withdrawal, although the New York Clinic was operated for only a pertod of ten months."2

\section{Closing the Clinies}

Arguments for and against the clinics have been made. They were closed, however in 1923, mainly from the physician's opinion that in the main they were not doing the job. Some arguments in favor say it got the addict into the open for treatment, stopped the peddling of drugs and the high cost which lead to the addicts having to commit crime to get drugs. The possession of. the drug itgelf is a crime. An addict was able to

\footnotetext{
IJohnson, op. cit., p. 299.

2 AMA Report, op. c1t., p. 2-8.
} 
keep sustained on the drug without having to spend time always hunting a peddler and providing the means (usually 1Ilegal) for buying it. The illegality of using arugs keeps the price up which in turn makes it very profitable to the pedaler to stay in business even though it involves much risk. 1

The meeting of the Committee on Narcotic Drugs of the Council on Health and Public Instruction of the American Medical Association conferred with the Attorney General in regards to the decision of the supreme court regarding the terms, "In the course of his professional practice only," and "prescription." The Attorney General agreed to prepare a case defining this position and not permitting the supply of drugs to go to addicts under the guise of cure. 2

The Behrman Case

The American Medical Association Committee also conferred with the Bureau of International Revenue, Treasury Department Giving the medical profession's attitude that it was the practice that the addicts were administering the drug themselves. They condemned all ambulatory treatment of addicts by either physicians or

I Ibid., p. 2-8.

2 Ib1d., p. 2-8. 
clinics. They urged the Internal Revenue Bureau to make use of its power to stop this. The Attorney General brought up the Behrman case before the supreme Court. Dr. Behrman had prescribed large quantities of drugs to known addicts, not knowing if they took them themselves or gave or sold the drug to others. As an outcome, it is now a regulation that a physician may not prescribe narcotics to an addict merely for the purpose of "gratifying his addiction." The clinics were closed in 1923. by the Narcotic Field Force. 1 Opening of Two Federal Hospitals for Addiction

Since then two federal narcotics hospitals administered by the United States Public Health Service have opened. The Lexington Hospital opened in 1935 for men and women patients on the eastern side of the Mississippi River. As New York City sends her patients there, this hospital will be studied. Lexington has 1200 beds of which 1100 are for addicts and the rest for psychopathic wards of the governmental services as the coast guard and other patients under the jurisdiction of the Public Health Service. No barbiturate user nor alcoholics are admitted, so heroin addicts are the main patients. Of the patients admitted $55 \%$ are allotted to

$I_{\text {Ibid. }}$ p. 2-8. 
federal prisoners and $45 \%$ to voluntary patients. Although $90 \%$ of the patients are voluntary there is no problem of beds as the turn-over is frequent and as voluntary patients many do not stay longer than to withdraw from the drug, hence do not really profit from their stay and are back again. Only $25 \%$ of the voluntary patients stay the recommended four to six months. Some stay a month or two thinking they are cured. 1

Ineffectiveness of the Program, Despite Many Services Other addicts stay only to keep out of jail as methodone given at Lexington is more painless than the witharawal sithout a drug as at jail. When the judge sentences the addict to jall he may plead to go for "the cure." He only intends to stay a few days and some even hide their equipment outside the hospital grounds so that they can have their drug again as soon as they get out. Some addicts have in mind to cut back their habit so that they get more of a kick with less heroin, thus making their habit cheaper. In 1955 of 3,638 addicts admitted to Lexington, $40 \%$ were recidivists. 2

ILieutenant Thorvald T. Brown, The Enigma of Drug Addiction, (Springfield, Illinois, Charles C. Thomas, 1963.) pp. 267-270.

2Ib1d., p. 269. 
There is a probation officer for the federal prisoners--those not comming voluntarily. Volunteer patients under twenty-one cannot come unless by the permission of parent or guardian. ${ }^{1}$ It was found that long imprisonment and parole was far more effective than mere long imprisonment. But unless a crime has been committed the addict is not put under parole. 2

Lexington's treatment is more complete than any other place with instruction or orientation, individual and group psychotherapy, occupational assignments resulting from psychological, psychiatric, and physical examinations and many types of recreational prosrams. Psychiatric patients are no more in number than for the whole of the United States. 3

There is dire need for follow-up care for Lexington patients. The addict returns to the same environment which sent him there with no help to rehabilitate him. He has no money or job and his family has not been to understand him. 4

A follow-up study extending as long as twelve years for those yet living was made showing that $30 \%$ of Lex-

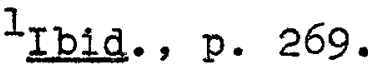

2Vaillant, op. cit. p. 734 .

3 Brown, op. cit.

${ }^{4}$ Vaillant, 10c. cit.
} 
ington's patients achieved good social adjustment. Most good outcome patients were functioning more adequately than they were before admission. ${ }^{1}$ other flgures say about $90 \%$ of those treated revert back to drugs and crime. 2

The New York City Penitentiary

The New York City Penitentiary was used to commit addicts under the Department of Corrections of New York City as there were no hospltal facilities. The stay was usually only on the average of a couple of weeks or until the physical withdrawal was over. There was no place to take the addicts, and they had no home in which to go. Figures do not speak well for the numbers who returned. of the voluntary patients who came from 1953 until 1956, 24\% committed themselves at least twice, $16 \%$ re-entered themselves two or three times, and $11 \%$ returned four or five times, while $10 \%$ came six or more times. It is doubtful they were "cured" even after that many committments as these short stays would only get the addict over the physical addiction. problem. 3

\footnotetext{
$1_{\text {Ibid. }}$

2Kobler, 10c. cit.

3 Brown, op. cit., p. 27.
} 
Bellevue and Riverside Hospitals

Bellevue Hospital opened 1ts facilities in 1950 for narcotics treatment. No more hope came with the opening of 180 beds at Riverside Hospital in the Bronx, New York in 1952 for addicts under twenty-one years. In the first five years of treatment of 3,068 patients treated some never came back, while others returned eight or nine times. The lack of mandatory controls for follow-up helped lose many and just because they did not return is no sign they were cured. There was a post hospital treatment set up. It was proven that it was a waste of money for hospltalization and no rehabilitation. Riverside Hospital was closed in 1963. The fact that relatively few patients have stayed off drugs since release is comparable to the federal hospitals. Post care should be strengthened. 1 Westside and Riverside Rehabilitation Centers:

These centers were to offer crafts and rehabilitation counsel. Riverside Rehabilitation Center has been closed, a. worker from the Westside Rehabilitation Center told the writer. The reason for closing was not disclosed. The worker, whose name the writer did not obtain, said that the center's purpose was not in preparing a man for a

$$
I_{\text {Ibid., p. } 271 .}
$$


41

job, but mainly for therapy.I

The Post Graduate Center of Psychotherapy

A free program of paychotherapy is conducted under the leadership of Dr. Marle Nyswander. It is sald that many addicts are accessible to psychotherapy. 2 When the persons were motivated on their own as some who volunteered for treatment, as in the Lexington hospital, it was found that $40 \%$ could be helped through psychiatric methods. 3

But when not motivated to give up drugs, short time help as a couple of weeks until the physical effects wore off was of little value. 4 It was not learned for how long a period Dr. Nyswander works with a particular individual or how successful her program is. It was learmed that she had formerly worked with Exodus House. She is currently experimenting with methodone as a substitute drug. 5 How much she is doing now with Psychotherapy is not known since the use of this drug.

\section{IIbid., p. 272. \\ 2íid.}

3harris Isbell, "Medical Aspects of Opiate Addiction." Bulletin of New York Academy of Medicine. Vol.31, December 1955, pp. 886-901.

$40^{\prime}$ Donnell, op. cit. 175.

5 ?" "Nó Way Out," Newsweek, October 10, 1966, p. 77. 
The Hogan Silver Plan

This plan was proposed by the New York State D1strict Attorneys' Association. It woula make manditory that addicts be hospitalized for as long as needed. It proposed a training program, preferably on a farm to train men for some useful place in society. It would provide appropriate psychiatric, spiritual, and other resources. With the training for some skill, vocational guidance would be given and referral to an actual employment situation. A plan of follow-up with periodic check-ups to be sure the person had not returned to his old habit. If he had, he would be recommitted. This proposal came from the District Attorney's Annual Report of Kings County, 1955. This plan was never adopted, I but proposals in it sound much like what was actually adopted and put into effect April 1967, but not entirely as there is no provision for a "farm program."

Methodone Prosram

In $1963 \mathrm{Dr}$. Marie Nyswander and her husband Dr. Vincent $P$. Dole of Rockefeller University started experimenting with the German discovered painkilier used during World War II. They found that this narcotic of the type to act upon the brain to produce a physical

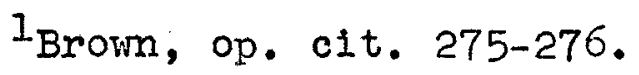


and psychic dependency. Withärawal produces characteristics and symptoms such as cramps, nausea, and chills. But methodone does not produce the euphoric effects associated with heroin. I It was first used to minimize withdrawal for patients being weaned from other drugs as was noted a.s used at Lexington Hospital.2

So the hundred and fifty patients under this nearly milizion dollar program sponsored by the City of New York line up for treatment at one of the following hospitals: Manhattan General, St. Luke's, Roosevelt, Harlem, and James Ewing Hospitals. 3 The patients who are carefully screened spend six weeks in a ward until proper dosage is established. Eventually, those taking shots from the "shooting gallery" as this part of the hospital is called and they the "winders" as the halls wind in and out, graduate to oral methodone. They are given this in orange juice as an outpatient and stops for his dosage each morning enroute to work. Eventually, the person is given a supply to administer

\footnotetext{
1 "No Way out." op. cit.

2 Brown, op. cit., p. 268.

3 Telephone conversation, June 7, 1967 with Miss Brandes of the Methodone Maintainence Research Program, Morris J. Bernstein Institute, Manhattan General Hospital.
} 
to himself, but must return periodically for counsel and a urinalysis to show if he is taking heroin again.I Dr. Nyswander cites the advantage of those in this program being employed. "More than half the patients under treatment for three to six months have jobs and eight out of ten who have taken methodone for a year are employed." Two of their patients have gotten four year scholaships for college. Dr. Dole says, "We can now define a treatment program that would work for a very large number of street addicts."2 Miss Brandes, secretary of the program told the writer, as cited, that the program employed a psychiatrist, doctor, social worker, and ex-addicts for implementing the program. They have vocational rehabilitation and counseling services. To what extent these services are carried out, it was not learned. There is a two year waiting list and not enough room for the present activities. They hoped the new program starting April 1, 1967 would bring them more money for beds. They claim an $84 \%$ cure. Miss Brandes reported that all patients were working or back in school as these persons have been in the program for some time. They are highly satisfied with results.

I___ "No Way Out," op. cit.

I Ib1d., p. 78 . 
Questions Raised as to Benefits

The consensus amons workers in other programs the writer visited that the program is not popular except in the eyes of the Methodone program and it is the writer's opinion that if more funds were to have come their way from the City, they would have known by that time. This program only puts the addict on a drug which makes it harder to withdraw from methodone than from heroin! The secretary admitted that none have been taken off the program as it is still an experiment. And indeed it is so for the patients would then learn that they were in deeper slavery as did Reid Kimbull, now director of Synanon that he had been a heroin addict for twenty years, but went on this. methodone treatment for a year and a half. When he wanted to "kick" the methodone habit, he had to go buy heroin to taper down! 'When methodone finally does leave the body, you go into withdrawal so excruciating you nearly die! It's that potent and insidious:" "I Amold Ross, also now free from all drugs as a Synanon graduate gives a similar story for his trial of a methodone cure when he tried to klck the methodone habit. He discovered he was unable to work without it as to

ILewis Yablonsky, The New Republ1c, August 13, 1966, p. 14-16. 
withdraw it gave stomach trouble and diarrhea so painful it is beyond description in polite society. Chester Stern, now manager of the New York Synanon, whom the writer met, says he was a heroin addict for twenty years and went six times to Lexington for "The Cure" and "cured" six times with methodone which kept him very comfortable as long as he had his beloved methodone, but when methodone was taken away he expresses the pain as "the marrow in my bones screamed." I

Not daunted by attempts to withdraw from this narcotic habit, Dr. Nyswander says, "we have to find out what the important factors in the treatment are besides methodone. Perhaps the use of the hospital as a temporary break with the street, combined with the encouraging presence of other addicts is vital. And what of the addicts who turn out to be resistant to methodone? We'Il have to find out whether their unwillingness to give up the "high" of heroin is psychological, has to do with intollerance to methodone or has some other cause.

But, even with all the remaining questions unanswered, I'm convinced that we have reached a stage at which the treatment of drug addiction can become firmly entrenched in the medical profession because there now

\footnotetext{
I Ibid., p. 14-16.
} 
is a medical procedure that can be taught, that can be duplicated, that can be executed. Further research will perhaps turn up better arugs--drugs that will be even longer acting."I

Mr. Lewis Yablonsky, author of this article cited feels strongly that "Maintaining a person as an addict on methodone or any other drug of this kind blocks the possibility of behavior change. My own obgervation of many cases reveals that a drug user is almost incapable of meaningful learning. A hooked addict is a basket case walking around in an emotional fog without will, amiably saying or doing anything that will continue his arug supply."2

Dr. Cavid Ausubel of the University of Illinois in the Journal of the American Medical Association cited in Newsweek asks this provocative thought be given an answer, "I fail to appreciate how legalized addiction is any improvement over illicit addiction." 3 Cyclazocine Experiment

This new drug shows some promise, but has been tested so little, it is hard to say if it will have any foothold in the treatment of addiction. It has the

\footnotetext{
l"Dr. Marie Nyswander," The New Yorker, July 3, 1965. 2 Yablonsky, op. cit. p. 14-16. 3 Ibia.
} 
benefits over methodone of not being addictive. "Cyclazocine reacts with brain cells as if it were a narcotic and on the cells' surface, blocking the action of heroin or morphine. It's like a wrong key, heroin can't get in."I

"But before cyclazocine is given, the patient must be first detoxified of heroin in the traditional way since a sudden dose of cyclazocine will bring on severe withdrawal symptoms. Once the regular daily dose has been reached heroin or morphine has no effect and hopefully the addict will lose interest in narcotics. This new drug is not a narcotic." Dr. Jerome Jaffe does not regard it as the final answer as itg effects last only twenty-four hours. "But the principle of narcotic antagonists," says its sponsor, "is that it immunizes the addict so that he no longer wants the heroin. This is a major development and longer testing of antagonists will undoubtedly be developed."2 The writer learned through asking various persons that the arug was used at the Metropolitan Hospital, but was given no encouragement as to any wide usage to take the time for further investigation as the impact is yet so limited. However,

I__No Way Out." op. cit. p. 78.

I Ibid. 
the. writer would like to follow through later to see If more is done with this drug.

Recent Lesislation

The New York State Narcotic Addiction Control in 1966 has adopted some very important pieces of legislation. This legislation provides for facilities to be established in the various municipalities for the care of addiction and called for stiffer legislation for the sentencing of addicts to such facilities. ${ }^{1}$ Private institutions already functioning and those which might spring up will be approved as satisfactory as to various standards which might be expected as to buildings, personnel, quality of care, and records. Then with such approval, those persons sentenced may elect to 80 to one of these places rather than to a governmental institution.2 Mid May, 1967 Hart Island Community Center was opened as a therapeutic community based on ideas gleaned from Synanon and Daytop, whose graduates have executive responsibilities. It is hoped that there can be counseling and vocational training as the program gets further under way. 3

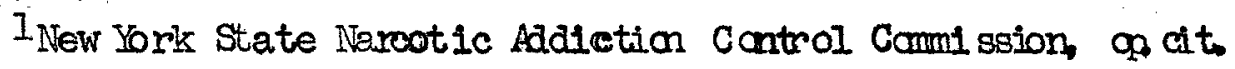
'Ibia.

3 Conversation with Dr. Jack Dav1s of Hart Island Community Center. 
Street Centers for meeting with addicts has been a forward step. Here ex-addicts have been hired who will show by example what can happen if the addict will avail himself of treatment centers. Mrs. Nancy Hoving, Assistant to Dr. Ramariz told the writer that they hope to soon have forty-five centers open in old store front buildings which type of place makes it more accessable for the addict to come and feel at home. 1

IConversation with Mrs. Nancy Hoving. 


\section{CHAPTER FOUR \\ PERSONALITY AND FANILY FACTORS \\ EFFECTING THE USE OF DRUGS}

Introduction

Chien suggests that it is not the economic deprivation found in high drug usage areas per se that causes drug addiction. But the effects of poverty are indirectly responsible. While the American dream has been shown him in school that everyone in America who tries has a chance for a glorious future, he sees too much reality in the lives around him who to him are much more reality than these utopian dreams. What he cannot have in reality, perhaps he can have in fantasy. This makes furtile soil for drug adaiction.1

Chien and his associates made a study using eighth grade boys from three different neighborhoods--one of the high drug usage, one of the medium, and one of low drug usage. The boys were taken from various junior highs and parochial schools. This age boy was used be-

IIsador Chien, et al., The Road to H, (New York, Basic Books, 1964), pp. 78-79. 
cause it was felt that they, being a bit younger were more unblased, yet were approaching the age when they might be using dmgs. They felt that these boys would have attitudes, values, and information or misinformation whlch would either deter them from using drugs, or would encourage their use. I Attitudes Found in Potential Addicts

A questionnaire containing a variety of attitudes, values, and information on problems relevant to the subject was used by Chien. Eleven questions were background information, as for example, did he live with his family? The remaining forty questions were ranged over the following topics: attitudes toward police, attitudes toward parents, agreement or disagreement with certain midale class standards of behavior, personal feelings of optimism, evaluation of certain life goals and adaptation of the items used by strole in his scale of anomie. 2

"The anomie items try to get at a lack of trust in people, a pessimistic outlook toward the future, and a sense of futility. Forty-five items: were explicitly related to narcotics and were divided among

\section{$I_{\text {Ib1d. }}$ p.80}

2 Ibid., p. 82 quoting from L. Strole, "Social Intesration and Certain Corollaries: An Exploratory. Study." American Sociological Review, 21, December 1956, p. 709-16. 
the following topics: attitudes toward the use of drugs, image of the drug user, action orientation with regard to the drug user, evaluation of arguments against using heroin, information or beliefs about drugs, and personal exposure to the use of heroin!l

It is true from the findings that those in the high drug rate area had more negative ideas expressed and also the sense of futility. Both strands of thought in this orientation favored use of narcotics, but the second (futility) not only associate reasons why they would not keep from drugs, but that it is good to take them for the psychopharmacological effects narcotics could give. The third strand showed an absorption of the drug subculture and delinquency that goes with it.? Comparative Study of Activities of Users of Drugs and

\section{Non-Users}

Another study by Chien shows the difference in the drug user group and a control group of non-users as to profitable activities. The non-users came from even more deprived neighborhoods than the users.

\section{Ibid. , (Chien) \\ 2Ibid., p. 106 .}


Use of Constructive Opportunities

by Users and Control Groupl

Percentage

Controls

Users

Used library or book club

Liked to read books on how to

63

28

lmprove yourself, explicit

mention in answer to open-

ended question

Was interested in extra-

curricular activities

Was active in extracur-

ricular activities

Went on camping trips, etc.

Stayed in school at least

until age 16

Total Cases

....3

17

50

40

22

88

(50)

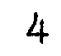

21

6

5

27

(50)

The non-users definately chose their friends while the drug users more or less stumbjed into those they associated with. The non-users stayed away from the users on purpose to avoid trouble and spoke of them as the "toughs," etc. Non-users were more likely to be associated in groups or clubs. They were more apt to be doing profitable things such as staying in school, reading books and talking about what they read to their friends. They had goals for themselves which. were more realistic, as a bicycle, while the users wanted cars, " a real expensive wardrobe," and pocket money. The

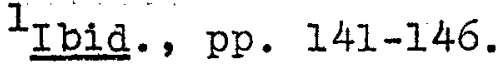


The users just spent their time "goofing off" or hanging around aimlessly, as at candy stores, going to parties and dances, and practicine of illicit sex relations. These conclusions were also gained from a study by Chien of boys who were users and those who were not. It is interesting to note the more, need for conformity among the users, who when asked the real reasons why kids take to drugs, $60 \%$ answered such as "to be down. with the cats," "follow the crowd," or "not to be called chicken." of the non-users, $39 \%$ gave this the reason.? Physical Addiction Compared to Psychological Addiction

It is pointed out that unless a user takes the heroin more than once a day, it does not have a universally addictive power. Many only take it on week-ends or for parties and though they follow this pattern for several years, they may be able to stop on their own. But there is a psychological need rather than the physical. This is when he craves it as a means of alleviating the distress of frustration, anxiety or pain. In this way he can cope with his problems. 3

This is. why mere detoxification from drugs is not enough. He still has the problems. Which made for his

\footnotetext{
IIbid., p. 142 .

2Ibid., p. 146.

3Ibid., p. 160.
} 
narcotic dependence. Those who have an increasing appetite are those for whom it meets some strong paychological need. Those who go from trying our narcotics to becoming a regular user are those for whom it satisfies a need or those with Iittle or no control over themselves. Through questioning boys Chien found that those who first took narcotics were I1kely to be in some depression, some emotional need, or because of some family stress. Some take dmags as a means to become less self-conscious as at a dance as they feared girls. Some were so immaturely bound to their mothers that for example, if they left a treatment center and returned to her, they were likely to go back on dmass. As studies to be cited show a low masculine identification, some tried it when they found themselves failing in the role of husband. I

\section{Personality Problems}

In clinical study the following psychopathology was observed among those who had become addicted-not just those who sometimes used narcotics and did not need them for support of some emotional personality problem:

1. Overt schizophrenia. Although these patients were not hallucinated or psychotically destructive, they displayed flattened affect, severe thinking dis- 
orders, delusions of reference and grandeur, and withdrawal social behavior.

2. Incipient schizophrenia or borderline. "These patients were struggling against an actively disorganizing and disruptive process in which they experienced extreme anxiety related to feelings of inadequacy and lowered self-esteem. Paranold trends and early thinking disturbances were noted. Though moralistic, struggling toward conventional goals in work, marriage, and education, they were unable to carry out the required roles and relationships. Their hold on reality was tenuous. In situations which put them under stress, they became unrealistic and confused. They strove to maintain intellectual control and to aroid situations requiring emotional participation.

3. Delinquency-dominated character disorders. "They were extremely hostile, defensive, provacative, demanding, and manipulative." of these they could be classifled into two groups:

a. Pseudopsychopathic delinquents. These patients tried to deny their passivity and dependency by trying to act "the bad man" as criminal, and strong and dangerous and were often seen in fights, robbery and assaults. They described this prior to and during drug use as pleasureable. 
b. Oral characterg. These patients wanted the role of nurtured and cared for and acted with rage when refused. They were easily upset and frustrated and the petty delinquencies they got themselves into were to punish and control gigniricant others in their lives. They almost said what they felt, "If you don't give me what I want, I'II be a bad boy and then you'II be sorry."

4. Inadequate personalities. These patients had few interests and goals and showed an impoverishment of thinking and emotional expression. They were neither "good delinquents" nor "good schizophrenics." They were successful in establishing role syatems in which people responded to them almost as though they were not there. 1

So there is no single deep-lying need or conflict common to or specific for addiction. Thus not finding any single problem the subjects were classified in the framework of psychoanalytic psychology.
A. Ego Pathology
B. Narcissism
C. Problems of Sexual Identification
D. Superego Pathology

Ego Pathology

"The ego refers to the aspects of psychic structure that regulates or governs the relationship between the

I Ibid., p. 195-196. 
world outside the person and the drives, impulses, demands, values, and goals within him. The ego is probably formed early in childhood or infancy which condition the perception of childhood and later experiences. Three major insufficiencies were found among oplate patients: response scope, synthesis and purposeful action."I

Response Scope.

They are relatively unresponsive to the outside world and to their own creative urged. When they were exposed to special opportunities for work or recreational skills they responded slowly or not at all. Their interests were few. Suspicion plays some role. There was a general lack of curiousity, lack of interest and a narrowing of the inlet of experience. 2

\section{Little Creativity Displayed.}

In the school at Riverside Hospital the teacher found that it was not a lack of creative ability for some could paint or draw, or do ceramics (a favorite) and they were interested as long as the teacher were there to urge them forward. But when she left they seemed to not perceive or respond. As was pointed out previously, they did not find the stimulating things

I Ibid.

I Ibid., p. 197. 
In the same environment which the "squares" did in an enrichment possibility in their community as for example the use of libraries and reading. While the "squares" played more active games and found life interesting, the users just hung around. I

Subjects were given several psychological tests and the Rorschach was particularly enlightening in that it showed the addicts to have a meager affective Iife and a more shallow and stereotyped fantasy ife. They showed up much more constricted persons than the controls. They lead much more impoverished and uncreative lives inwardly and outwardly than the situations required of them. 2

It suggests that they are uging defensive constriction when they showed they could be creative, but would not unless pushed. It may be that they have tried responses to environmental stimuli which presumably offered reward, but they only found the same bleak disappointment until in protecting oneself against further hurt, he stopped responding at all. This could happen to the adolescent who repeatedly found failure in school his lot or for the Negro who repeatedly was refused work

$$
\begin{aligned}
& I_{\text {Ibid. , p. } 197 .} \\
& 2_{\text {Ibid. , p. 197-198. }}
\end{aligned}
$$


or opportuntities because of color. ${ }^{1}$

Constriction is highly protective just like an airtight air conditioned room which is also windowless. Something must have happened to the ego structure early in life to cause this.?

Synthesis of Ego. "This is referring to the ego' functioning to a complex of activities which have to do with the organization of that perceived and with the coordination of conflicting needs. It is silent and largely preconscious or unconscious. It concerns questions which can be answered by conscious intellectual thinking as is seen in the addict. who knows all the harms of addiction, but is unable to make use of the information and does not belleve it can happen to him. He has poor synthesis, as he should see in asking the questions of himself, "What will happen if I do this?" How will I feel about it later? Judgment, reality-testing, delaying, accepting frustration and moderating between alternatives are involved in synthesis." 3

Addicts who have this type ego are unable to apply themselves to intellectal tasks even though they know that to get a job, it is necessary. "Situations which

${ }^{I_{\text {Ibid. }}, \text { p. } 200 .}$

I Ibid.

3 Ibid. 
are unpleasant, painful, or anxiety-provoking make special demands on the synthetic function of the ego. In a painful situation, the least difficult and most immediately effective behavior is to witharaw or to strike out angrily and directly against the source of displeasure. As this is not always feasible, the addict in the presence of what he thinks harsh, insult or criticism, leave the field. They quit jobs because the boss speaks harshly to them."I They would rather quit a job that has been criticized than to look at the reason for the criticism and profit by it. So early in the history of their addiction, they typically experience withorawal symptoms. The drug itself helps in this isolation and natural witharawal they feel psychologically anyway. Mostly their behavior is withdrawal, inhibition and passive dependent strivings, but sometimes it is actively striking out. Whether the response is active or passive from a standpoint of synthesizing they are acting inappropriately.?

Rorschach ink blot tests used by Gerard and Kornetsky show that addicts are not only typlcally lessable than control groups to make additional output but show a marked deterioration in performance under stress of

\footnotetext{
${ }^{1}$ Ibid.

I Ibid., p. 201.
} 
such a demand. "Their reality-testing becomes less efficient, and their emotional participation and perception becomes regressive." I

Evasion of Maturity a Most Dangerous Aspect of Adaiction

The major difficulties usually experienced by adolescent are conflicts over autonomy, genitality, and particularly identity, but as they are usually handled gradually and in progressive steps, he is able to handle them. Relationships are established, skills acquired and improved and roles clarified in many situations. But the adolescent who has taken up addiction as a way of meeting iffe has sidestepped the steps of leaming by avoidance of situations whereby he could have learned by just going along with the whims of others and being passively lead around by them. Eventually, he substitutes the anxiety producing normal things which come to all for drugs. "This evasion of maturity is probably one of the most dangerous and seducive aspects of oplate use." 2

Purposeful Action. The adolescent addict appears lazy, slowed down, halting, shows difficulty in starting, stop-

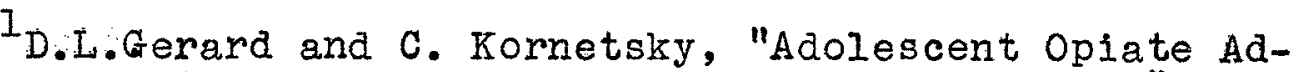
diction: A Study of Control and Addict Subjects," Psychiatric Quaterly, 29, 1955, pp. 457-486.

2E. Erickson, Chllahood and Society, New York, Norton, 1950. Quoted by Chien, no page given. 
ping, or changing mid-stream when even though they have started to do something purposeful, despite their constriction and lacis of synthetic capacities because of weak egos. This is often seen in those who should enter the hospital for detoxification. The delay may be mistaken for stubbornness, or purposeful action to delay treatment. He commonly seeks an outside person to incarcerate him or bring him to the hospital, even if he wants it for himself. I

Narcissism. At first, a baby sees itself only as part of its mother. The others in his life are but extensions of himself. He has but to cry and a hand comforts him or he is given food. Later, a second stage is when the child sees himself more or less sharply defined from the not-self, but that other self should always be still serving him. He never quite perceives them as to their objective properties. If he does not pass from the first stage there are certain maladaptive consequences to personality development and so are there if he cannot pass on to the third stage. It is somewhat a return to stage one, but now he can see himself realistically as to his own capabilities and accomplishments as well as seeing others objectively in the light

${ }^{I_{\text {Chien, }}}$ op. cit., p. 203. 
of theirs. Mature love is possible when the person wants another to be ahppy. It is also accompanied by a sense of his own personal worth which is rooted in a realistic assessment of his own abilities.I

But the adolescent addict is still in the second stage and sometimes regresses into the first. His association with the outside world is meager in establishing sympathetic and empathic relationships with peers and adults. But his mother is still the center of his life. It is a relationship with another to gratify many infantile impulses. She is still part of himself. This is not a warm loving relationship or one of concern for her welfare, but has a comgination of feelings about her-love, fear, and hatred.2 Problems of Sexual Identification

There is a low self-esteem among addicts, even before addiction. They are burdened by feelings of weakness, inferiority, and less self-esteem than other disturbed youth. To cover a weak self-identification, he puts on a front of a group identity as a "junk1e" and to him this is supportive. Because of their weak selfidentification and that most lived with no father figure (as found by surveys made), the boy has a hard time

\footnotetext{
I Ibid., p. 205.

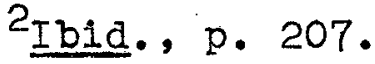


thinking of himself as a male. He primps and dresses and worries about wanting expensive clothes as does a girl. He does not want the responsibilities of a male--which means getting a job, taking responsibility, and power and character strength. They have not become providers for their families. They are soft-spoken and graceful and well-mannered. As a group they are better looking than the control groups interviewed, with usually handsome faces and well formed bodies. Thus they are vain in their appearance. They are not unlike ordinary adolescents, except in degree. ${ }^{1}$ These observations are that they have strons female identifications. The writer noted one addict wearing pink nailpolish. Of course, there are exceptions. Yet their defensive and compensatory behavior tries to cover this in trying to define manhood as in refusing to obey rules, etc., as in an institution. The conclusions of Fort, ${ }^{2}$ Zimmerman, and the Chicago Clinic ${ }^{3}$ support

\section{Ibid., pp. 217-225.}

2J.P. Fort, "The Psychodynamics of Drug Addiction and Group Psychotherapy," The International Journal of Group Psychotherapy, V, April, 1955, pp. 150-156. Quoted by Chien, p. 225 .

3P. Zimmering, J. Toolan, R.S.Safrin, and S.B.Wortis, "Heroin Addiction in Adolescent Boys," Journal of Nervous and Mental Disorders, 114, 1951, no pase" - 1 iven as quoted by Chien, p. 225. 
these views. ${ }^{1}$

"As these young men with basic lack of male identification grew up they tried to cover up this feature of their personality by violent aggression; many joined street gangs, which helped spread their guilt feelings about their aggressiveness and also gave them more support to their doubtful decisions to be a man. At the same time, society gave them plenty of opportunity to project their hatred of it--a vicious circle. So addiction was a way to escape from unhappiness caused by the aggressive feelings. Most of the Negroes had strong ambition but had an equaliy strong bent not to succeed. Success amounted to a destruction of their justification for turning their hostility against society and perhaps also represented a betrayal of the whole racial group for the same reason. Many Negro patients had, upon achieving considerable success in aftistic lines, immediately began using drugs and sank rapidly into utter failure." 2

Drugs as a Substitute for Masculinity

Fort was told by addicts that psychological meaning

I"Drug Addiction among Young Persons in Chicago," A Report of a study conducted by the Illinois Institute for Juvenile Research and the Chicago Area Project (October 1953) as quoted by Chien, p. 225.

2 Fort, op. cit., p. 84. 
came because of the use of heroin. "The intravenous injection of heroin or heroin with cocaine hit them in the intestinal region or a few described it as in the rectum. It was a warm glowing sensation, and spread over the body and could be compared only to a sexual orgasm. They described it as responsible for both their ills and the source of their only pleasures. Since these patients are not sure of their masculinity, this serves its purpose, but they felt great guilt in doing so. When asked about an injection, some said they thought of their mothers with sexual desire and then their guilt intensified. ${ }^{1}$

Others felt their world was blown up--a great destructiveness to self and the external world. One patient described his feeling as "purified" 2.8 if he were depersonalized and numb. After the orgastic feeling he felt profound relaxation and a sense of contentment; the sense of guilt had vanished. Patients reported a sinking into a feeling of suspended animation. At times this would be followed by grandiose feelings and fantasies, and all problems would then seem easy to solve. They might even think calmly about personal problems. Which before had seemed enomous. They

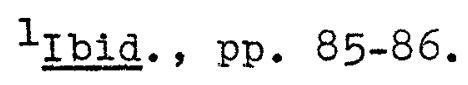


might even plan a solution to a problem as leaving home, but. when coming back out of the drug they had even forgotten it or were unable to do it. The man under drugs is not aggressive, but sober, cowardly, and a nonaggressive idier whereby he might have previously been a drunken fighting psychopath in trying to get money for his drug. This if for the heroin addict, but not for the other drugs which cause aggression. Withdrawal has a good deal of masochistic gratification. 1

He cennot stand the loneliness of complete withdrawal, but he finds that some of the intensity of his drives can be reduced and turned inward through the relatively simple mechanism of drug use. He can, as it were, with one short act accomplish the destruction of the external world and of himself and can achieve a libidinal goal with orgastic pleasure. Such a phantasmagoria of psychic effects can in fact be observed in greater or lesser degrees in many young men addicts.? Rado has said, "Erotic gratification by means of drugs is a violent attack on our biological sexual organization."3

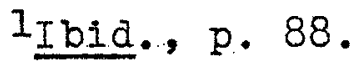 \\ I Ib1a., p. 89.}

3s. Rado, "The Psychoanalysis of Pharmacothymia (Drug Addiction), Psychoanalytic Quarterly, 1933, 2:1-23. 


\section{Drugs as Status Giving}

To be an addict also gives him status and a society all his own to which he can identify. Before addiction, he was an isolate and withdrawn. Now it gives him a ceremonial gang association with jargon all its own. Their life consists in making contacts with those who sell drugs.

"The problem whidh the potential heroin addict faces seems to be the same as that of the schizophrenic. He is unbearably frightened by the enormity of his hostile, destmuctive drives."I

Relief from Anxiety

Drug taking is not what the normal thinking of "experiences of the high", but are really to give relief from anxiety within and without in his world. It is a negative type of pleasure as Nirvana represents an ideal of fulfillment through absence of desire. The desire is itself viewed as an inherently frustrated state that cannot be compensated for through the pleasure of gratification.2 The contact he has with the painful reality is reduced. Ideational and fantasy are

\footnotetext{
IChien, p. 89.

"Drug Addiction Among Persons in Chicago", op. cit.
} 
increased, which are in this way blotting out the disquieting fantasy life of wealth and status as when under the drug. "Awareness of tensions and distress is markedly reduced; contact with reality diminishes."I

"Here in junkie paradise the natural desires of hunger and thirst, sexual desire, awareness of pain are obliterated and their bodies satisfied and sated."2

Craving is not an isolated or automatic psychophysiological dependence; indeed, it can occur in the truly addicted individual even when he has been completely relieved of physiological dependence of the drug. Some find the craving has returned when supposedy cured as the complex interpersonal relationships which were primary underlying causes have never been dealt with. Such was the case of one son when he returned to his mother after supposedly being cured. Another reason is that they find. satisfaction in being involved in a culture, a feeling of belonging, a place in society and indeed a vocation as an addict. Craving is not a response to emptiness, but a satisfying of minor anxiety,

\footnotetext{
"Drug Addiction Among Persons in Chicago" op. cit. Chien, op. cit. p. 232.
} 
frustrations and pain by an intense desire to a sort of intrauterine-like state of apparent self-sufficiency which the arus can induce."I

"When the adolescent tries heroin for 'kicks,' he is trying to experience something different in the vain attempt for happiness. He only finds that it is a negative 'kicks' of relief from his physical drives as heretofore explained."2

"Camouflaging anxiety beneath the haze of an altered state of consciousness, opiates may harm the person in his development. By offering immediate relief from tensions and anxiety prevent growth processes." 3

\section{Superego Pathology}

The superego is the conscience which screens out behavior not accepted by themselves through what he has been taught by his family. The addicts were found to have a pathological superego. The total family situation was studied by research using as controls those who lived in the same environment. Ethic groups were studied separately as native whites, Negroes, and Puerto Ricans. It was found that the poor superego factors were: inadequate masculine identification,

\footnotetext{
$I_{\text {Ibid.. p. } 228 .}$

I b1d., p. 239.

3 Ibid., p. 366 .
} 
lack of unrealistic levels of aspiration with respect to long-range goals, and a distrust of major social institutions. The kinds of backgrounds were studied. One group made for inadequate internalization of socially accepted standards, the other making for an overly severe and punitive type of superego functioning. Both types were found more frequently in the addict's family background. ${ }^{1}$

Were it not for the legal aspects of addiction, the addict might be passed over as less than a problem than the drinker or chronically unemployed. But as a human he deserves our attention the same as other persons with neurotic problems and whether he had drugs and was an addict or not, he would still have his personality inadequacies. Just to take away the drug, which is serving to reduce anxiety for him, is cruel, unless he is helped to find a higher form of adaption.? Family Background of Addicts

In Vaillant's Twelve Year study of a hundred New York city addicts certain facts point to a disturbed family background of addicts. "Twenty percent

$I_{\text {Ibid., p. } 268 .}$

IIbid., p. 366 . 
of the patients lost their mothers before age sixteen and $50 \%$ lost their fathers before that age. Before age sixteen, 53\% lost at least one parent. These figures are higher than for those observed in mental 11lnesses other than sociopathy. Of 78 addicts who remained with their mothers until age sixteen and who were physically addicted, $32 \%$ were classed as good outcomes. Of the 19 addicts who remained with their mothers until age sixteen and who were physically addicted, only two were classed as good outcomes. Nevertheless, $30 \%$ of the motherless addicts were abstinent for at least a year while under compulsory supervision, compared to $25 \%$ of the addicts who had not lost their mothers."I

"In $62 \%$ of cases, at least one parent came from a culture aifferent from that of the patient. By this is meant that although born in the United States, the patient had at least one parent born in the southern United States. The birthplaces of our 100 addicts were compared with those in the 1960 U.S. Census data for New York City for males of gimilar age and race. The Census data revealed that probably a third or less Puerto Rican, non-Puerto Rican white and Negro

Vailiant, op. cit. p. 733. 
youth males were born in the northern United States yet had forelgn or southern born parents." Thus, disparity between childhood culture of the addict and that of his parents appeared positively correlated with likelihood of addiction. I

Chien found striking contrasts between the control group and the addict group in the relationship of the boy to his father. In half of the homes there was no father figure at all for some significant time period. If the father were present there was emotional distance or hostility toward the boy. Also, when present, the father was often of immoral character with respect to criminality, infidelity, alcoholism and the like. They had unstable work histories, had pessimistic and fatalistic attitudes toward their future and often held unrealistically low aspirations for their sons' future. 2

In $97 \%$ of the addict families there was a disturbed relationship between the parents as separation, divorce, open hostility, or lack or warmth and mutual interest. Almost invariably there was an absence of a warm relationship between son and father in the addict's home.

\section{IIbid.}

2chien, op. cit. p. 274.

3 Ib1d. 
Discipline

Discipline was vague, or inconsistent. In $70 \%$ of the cases the child was overindulged, overfrustrated, or experienced vacillation between the two. In about a fourth of the addict homes, but none in the control homes, there was evidence of an absence of a clear pattern of parental roles in the formation or execution of disciplinary policy. 1

Religion

"Much difference was noted between the control's religion which was meaningful and personal while the addict's was formalistic and only ritual, empty of meaning, and manipulative in trying to get from the divine, what was wanted."2 The Male Addict and His Mother

In the relationship of the addict to his mother there are differences between them and the control group at statistically significant levels, but this only for a minority of the cases. Here the mothers were hostile and emotionally distant to their sons who became addicts. They distrusted the major social institutions as the school, and like the fathers had unrealisticaliy low aspirations for their sons, which reflected

${ }^{1}$ Ibid.

I I Ibid. 
their own attitudes toward life of pessimism. They had weak relationships to their sons.

The other mothers show an early sustained disturbance in mother-son relationship. The relationships are complex and individualized. 1

${ }^{1_{\text {Ibid. }}, \text { p. 274-275. }}$ 
Seclected Single Itemg on Which Addict and Control

Family Backgrounds were Highly Contrasted

Percentages

Addict Control

1. Boy experienced an extremely weak

father-son relationship.

.80

45

2. For a: significant part of early

childhood, boy did not have a father

figure in his life.

48

17

3. Some father figure was cool or hostile to boy.

4. Father had unrealistically low

aspirations for the boy (late

childhood and early adolescence).

44

0

5. Some father figure was an im-

moral figure.

23

0

6. Marked impulse orientation in

father figure.

26

7. Father had unstable work history

during boy's early childhood.

43

1.4

8. Father was unrealistically pessimistic or felt that life is a gamble.

9. Lack of warmth or overtly discordent relationship between parents.

10. Mother figure was more important parent in boy's life during late

childhood period.

11. Some mother figure cool or hostile to boy (early childhood).

12. Some mother figure cool or hostile to boy (late childhood). 
13. Boy experienced extremely weak 40 mother-son relationship.

14. Mother did not trust authority figures.

15. Mother had unrealistically low aspirations for boy (late childhood and early adolescence).

16. Mother was unrealistically pessimistic or felt that life is a gamble

17. No clear pattern of parental roles in formation of disciplinary policy (adolescence).

18. Parental standards for boy were vague or inconsistent (early childhood).

55 4

19. Parental standards for boy were vague or inconsistent (adolescence).

20. Boy was overindulged, frustrated in his wishes, or both.

70

The number of samples used for each group usually was about 29 and 30 , but in some cases where the questions could not apply (as when no father was present) less numbers of cases were used, but none less than 16 and this only in one case.?

The interviews of families was conducted by twelve advanced students from the New York School of Social Work and from the School of Social Service of New York

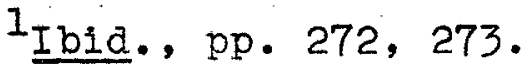

2 
University. Two to four interviews per family were made. After interviewing the caseworker filled out a check-list questionnaire designed to compute index scores of family experiences predicted for each of the personality and attitude characterisitics. The caseworkers were not informed of the predictions until all material was collected. 1

\section{Summary}

These young men were not the slum children, although they lived next to slums. Few knew poverty. So we cannot say, that addiction is because of poverty. 2 This was voiced by Tom Macher, a resident of Daytop, who said not many of their residents could have been classed as poor. He himself spoke as though he'd had everything. The writer wonders however if their group located in a good neighborhood is not more select in their willingness to come to a "nice place" rather than one like Exodus House in the midst of slum conditions which it was felt by the writer poverty did exist. But at least, we may say that there are certain personality and family constellations which seem to tend to make some persons wish drugs.

\footnotetext{
IIbid., p. 266 .

Fort, op: cit, p. 77.
} 


\section{Female Addicts}

In studies made by the same team it was found that the environmental story for the female addicts was not unlike that for the boys. A notable exception, however was in indexes of unrealistic aspirations for the children and distrust of major social institutions were found lower for the families of female addicts than for boy addicts. They were not ignorant of the harm of drugs, were not "taken in" by some older pusher, but through curiousity asked to try from a female friend who reluctantIy gave them their first try. They then supported their habit by living with a male pusher, friends, or prostitution 1

Effects of Family Living on Child's Creativity

of recent years much is being said and written about the "culturaliy deprived" individual, which certainly fits the drug addict. Coming from homes which do not spark creativity we would expect to find the flattened personality types seen in addicts who would rather just loaf around than do anything productively creative. Their lives are so dull that to put themselves into a

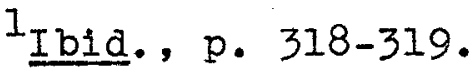

${ }^{2}$ Bernice D. Ellinger, "The Genesis of Creativity" The Reading Teacher, Vol. 19, \#7, April 1966, p. 496. 
state of "not being" is more pleasureable than "being!" What are the qualities found in family living which correlate highly with creativity?

Family activity (doing things together for work and play .490

School Emphasis .481

Intellectual stimulation .556

Emotional Climate .450

Parental Expectation .433

Life Model .465

\section{Slum Children's Conversation}

To better conceive how the child growing up in the immediate environment feels about addicts and why he may later seek to use such listen to the conversation by Negro slum school children as reported by their teacher:

Richard arrives half an hour late to school. During the night, addicts had stumbled onto a pile of broken plate glass on his street, then into his bullding to sleep. His father, the superintendent, had found the hall so full of blood at early dawn he'd gone to the police station before getting the addicts out.

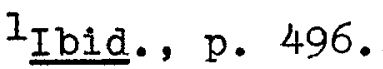

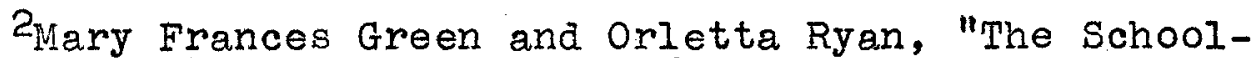
ch1ldren." Random House, 1965, p. 77. 
Richard: The lieutenant told him, "Dial my private number. I'Il send every man in the place out." Monty: "They gets blood on the floor because they misses their bein, too.

Richard: "They sleep on garbage buckets in the basement. My father tried to get 'em out with his Derringer; but sometimes they get so high they can't get off the piles."

Reg8ie: "But they can't help theirself. It's their Iife. They don't want to hurt no one, just their selfs." Monty: "You has to be careful with that needle, and be sure you go to your vein, and carry a baby's nipple over the tube or you hurt someone." Regsie: "They feel they in the snow walking in tennis shoes in the snow. They feel like they in another world. I don't mind if I was an adict--they warm in winter." (Note positive attitude toward dmag use.)

Richard: "The reverend in our church, he tried for years to he'p them, but he say he about ready to quit. They do be so greedy, the reverend had four chickens for Christmas for poor, and the adaicts come and eat them all."

Ruby: "Children must stay away from them, they kisses you in a funny way, they wants to expose you. They splits open some candy and fill it with gray powder. 
They wants you to get funny with them."

Monty: "An adaict always brings his equipment with him. Cover his needle with a baby's nipple, and he need a big black belt for his arm so he can set that needle right in his bein." (rather admiring her worship) Richard: "They cut when they sees the cops. The cops swing up they billies; they polke to the addicts chin." Virgil: "Oh, there was an addict and $I$ was so scared. I had my mother's twenty dollars; I was going down to the store. He come up behind me and put a knike on me and say, 'Don't turn aroun, don't breathe,'. Sometimes I'm nutty, and I run away! And I was lucky. You gets it right there." (Shows on his back)

Noah: "My father was adic', he went down to Florida, got higself cured. No addic' can work, no addic' ever been known to work, except when he were a small child."

Malcolm: "But you can't just start addict. First, sniffin glue; you 'bout nine. Later you goes on reefers. on the roof with older kids. My brother smokes reefers, but he won't let me come up, he say he'Il tan me. (Might like to try.) About ten hangs out on my block. My super keep them moving in our hall. We live on the first floor, my mom got a police lock on our door. But it's scary. They call in soft through the keyhole when my 
mom is out. My mother don't answer that door at night. She says, 'Who's there?' But don't open it. And she keeps a can of Iye by the door."

This no doubt is daily school conversation. Malcolm, Monty, and Reggie do not have too adverse feelings regarding the use of a drug for themselves later on. 1 How the School Can Improve the Education

The present addict has grown up in homes and has become the school drop-out of a system of education which did not stimulate his imagination, give him realistic goals, or means of attaining them. It is at least a step in the right direction that not only educators, but that from the President down things such as Head-start, Surrate Grandmother Programs, Great Cities Projects, and various title programs have given money to help stimulate education. The U.S. Employment office has a youth branch, the Youth Opportunity Center which is designed to give more counseling services than the adult offices for hard core youth. Schools Geared to Midale Class Children

A host of books and articles have been written and experimental projects as conducted by Martin. Deutsch in working with the Institute for Developmental Studies of the Department of Psychology of the New York Medical

\footnotetext{
$I_{\text {Ibid. }}$ p. $78-81$
} 
School. They have pointed out what can be done particularly in the crucial early years of a child's Iife to overcome the difficiencies found in his home and school. Schools have been designed for the midaleclass child and when the lower-class cannot compete, he becomes more and more discouraged and further from those whose intellectualism might stimulate him. Since he needs education for a vocation and has probably dropped out of school with no skill, he becomes aimless and just loafs on the streets. As he cannot have the things he sees middle-class familieg have through hard work, he daydreams, but daydreams are frustrating. So when he hears what narcotics will do for him of taking the desires away so that he is happy without gratification, he finds drugs something needful for him.I Hopeful Methods

In education, however, Riessman suggests that the creative teacher approach will not work for these culturally deprived children, much as we would like to see creativity fostered which the writer of this project feels would tend to make for a personality

ICarl Bereiter, Siegrried Engelmann, "Teaching DisAdvantaged Children in the Preschool": Institute of Research on Exceptional Children, University of Illinois, Urbana, IlIinois, Prentice Hall, Englewood Cliffs, New Jersey, 1966. 
structure that does not need a drug. But he suggests this is too great a step and that a marriage between the old traditional authoritarian school (however, with a warm, understanding teacher) along with some creative methods is what can be used to best advantage now. Too many features are alien to the child such as permissiveness (accent on self, internal introspection, creativity and growth as central goals, )stress on play, underestimate on traditional attitudes and personality characteristics of the deprived child. He suggests in this "marriage" that it have structure, rules, discipline, order, organization, and strong external demands for achievement. 1

The writer of this paper is postulating that the factors sugsested for education are the same as those which have been found to use in methods in treating addicts, which have been the most successful. For in fact, those working with addiction with the most true success of getting a person off any dependency drus are using an educational approach--a reeducation of the the addict.

I Frank Reissman, The Culturally Deprived Child, Harper and Brothers, New York, 1962. p. 71. 
Stigma of Being Negro

It has been found that for the Negro the inferior caste position marked by matriarchal type of family Iife has been detrimental to the self-image and particularly for boys in the "no father" home or "weak father-type home." Way before the Negro child enters school he becomes aware that to be black is not to his advantage and he even resists identifying with his own family. The girl will select a white doll or white playmates and seek to identify with a white woman rather than her mother. This results in ego-deflation. I

The Negro boy finds maleness depreciated in the matriarchal home. Early experiences of fending for himself results in too early social maturity, inde-pendence and emancipation from the home. Girls tend to develop a better ego structure, probably from their more favored position in the home. Because of the socially rejecting culture for the Negro he has a deeply ingrained negative self-image. ${ }^{2}$

${ }^{I_{\text {David }}}$ and.Pearl Ausubel, "Ego Development among Segregated Negro Children," Education in Depressea Areas, A. Harry Passow, ed. Teachers' College, Columbia University, Bureau of Publications, New York, 1963, pp. 109-141.

I Ibid., p. 141 . 
"The alienation of the children by the school results in the rejection by the children of the school. Our society alienates the economically deprived and in turn they reject the society."I

Sugsested Improvements for Advancing Negro Children

It is suggested that it is more humane to "weed out" teachers who are racially biased as to weed out the children who become so discouraged and lack so much self-confidence that they drop out. Also more should be done to indicate to the children of all races that democracy is truely raceless and casteless by putting into the reading and social studies books examples of what minority groups have done in our country of note as well as in the world. P.ictures using only white middle-class families with a prosperous looking father returning home from work carrying a brief case into a suburban home also gives the idea that he is the only valuable father to have. The contributions of factory workers' fathers could be show or other lesser positions. 2 These would give a more realistic picture and not such high goals which because they become unattainable the student daydreams

I I id., p. 142.

Svathaniel Hickerson, Education for Alienation, Prentice-Hall, Englewood Cilffs, NeW York, 1966, p. 72, 95. 
and as pointed out has its effects on drug addiction. I Higher Horizons Program

In schools in New York Negro History Week is almost universally celebrated with bulletin board displays of pictures of Negroes at work in the community; the children investigate lives of Negroes who have contributed to society, and supplementary reading of books or poems by Negroes and music written by them. In the elementary grades where the self-concept can first be reinforced are full length mirrors, photographs of the children and many opportunities to use the child's name in writing in public.

Field trips are necessary as many in Harlem have hardly gone a few blocks from home. Or the world can be brought to the school in displays of various kinds, travelogues, pictures, interesting personalities and art to broaden interests. 2

$I_{\text {Edmund W. Gordon, Doxey A. Wilkerson, Compensatory }}$ Education for the Disadvantaged, College Entrance Board, New York, 1966, p. 73-74.

I Ibid., p. 74 . 


\section{CHAPTER FIVE \\ Treatment Centers studied}

\section{Synanon}

The writer visited New York on two different occasions to visit what is felt to be a representative group of treatment centers. A complete list of such centers is in the process of being made by the office of the Coordinator of Addiction Programs for the City of New York. The writer learned of these centers through magazine articles and word of mouth. The writer regretted not being able to have spent more time at each of these centers and in so doing, to have gone into greater depth.

The centers studied and visited are: Synanon, Daytop, Exodus House, Hart Island Community Center, The Haven, the Christian Reformed Church, Teen Challenge anà the Damascus Christian Church.

\section{History of Synanon}

Synanon got its name because of someone who could not pronounce seminar and said synanon. The name has thusly clung in referring to this unique organization, 
and has been adopted as the name for the large organization emerging here and there of treatment centers. It was learned that the. New York Office only housed nine addicts. This was learned upon the first visit on June 8, 1967. The writer felt it was a pretty fancy. house with only so few--sounded like pretty plush living on this elete address of 35 Riverside Drive. However, upon the later visit, when an open house was held Saturday night at 9:00 July 8 th that this was only for executive business for the seven houses. An open house is held in each house each saturday night. It is open to the public to learn of the group's work. The other real institutions, are located at: San Monica, the original started by Charles Detrich in 1958 when as an active member of Alcoholics Anonymous drus addicts were attracted to him for companionship. The music and talking got so loud he was asked to move. Then a store front bullding was rented and with an employment check of Detrich's the idea grew. Later the old armory building was taken to house the group. Protests from the residents came, but synanon survived in this location. It spread to San Diago, San Francisco, Domales Bay, Tannersville, New York, New York City and just opened in mid June in Detroit. The New York City building does serve as a center in that persons may come 
there who are interested. When carefully screened they are sent by plane on to California. The governor of the state of Nevada asked for Synanon folk to enter the prison and carry on discussion groups and similar activities for its addicted inmates. This is also being done in California prison. A film was shown of this work the night of the open house.

The Games.

Besides the resident houses, there is a wider program called "The Games." It is sort of a table game with eight to ten playing. It was not learned if one played it with dise in order to make the moves, but it could be invisioned that one would. Spaces with words such as "They talk about your beard." (go back two spaces.) "Do I have to talk about it" is another space or "React to your weight problem" lose four, or "Lle manfuliy," don't move. A group is playing the game at the Berkeley campus in California. A big hall is set aside to play it in Santa Monica called the Santa Monica Game Club. These persons are "normal"--no serious character disorders who come to play this game of verbal interaction once a week. The game can turn into anything; it is not labeled therapy, but if a person lies it gets mighty uncomfortable and he usually leaves. One psychiatrist came and only wanted to know about the other people and would not talk about his own 
weaknesses. He wasn't playing it fair and was more or less booted out. Or if lieing is too uncomfortable they come around with the truth or get out. Rev. C. Mason Harvey, a Presbyterian minister was an ally of Synanon and asked that the "Squares" or normal people be allowed to play the games, which originated with the addicts. So the games became a part of thousands of lives once a week all over the country. Rev. Harvey felt it harder for the "squares" to tell the truth and let down their hair than the addicts. So in each Synanon house the game is played three nights a. week-Monday, Wednesday, and Friday evenings. Anyone can join the addicts of these institutions to play. Some come regularly.

\section{The Synanon Philosophy}

The Synanon Philosophy is based on the belief that there comes a time in everyone's i1fe when he arrives at the conviction that envy is iBnorance; that imitation is suicide; that he must accept himself for better or for worse as is his portion; that tho' the wide universe is full of good, no kernel of nourishing corn can come to him but through his toil bestowed on that plot of ground which is given to him to t1I1. The power which resides in him is new in nature, and none but he knows what it is that he can do, nor does he know until he has tried.: Bravely let him speak the utmost syllable of his conviction. God will not have his work made manlfest by cowards.

A man is relieved and gay when he has put his heart into his work and done his best; but what he has said or done otherwise shall give him no peace. As long as he wllingly accepts himself, 
he will continue to grow and develop his potentialitieg. As long as he does not accept himself, much of his energies will be used to defend rather than to explore and actualize himself.

No one can force a person toward permanent and creative learning. He will learm only if he wills to. Any other type of learning is temporary and inconsistent with the self and will disappear as soon as the threat is removed. Learning is possible in an environment that provides information, the setting, materials, resources and by his being there. God helps those who help themselves.

\section{SYNANON PRAYER}

Please let me first and always examine myself. Let me be honest and truthful.

Let me seek and assume responsibility.

Let me understand rather than be understood.

Let me trust and have faith in mygelf and my fellowman.

Let me love rather than be loved.

Let me give rather than receive. I

\section{Synanon Therapeutic Methods}

No drug is used or method of detoxification--just cold turkey. But it is much easier to do on a couch with others around going about life as usual, singing, smoking or what not. Occasionally a person is put to bed. Residents come voluntarily and are given anything but the welcome mat. They about have to break the door down to get in, really showing sincere desire to get well. They want the person to come on his own, not being sent by someone. They ask for money, figuring

\footnotetext{
$1_{\text {Mimeographed sheet passed out at synarion. }}$
} 
that "where a man's heart is, there will his treasure be." However, no one is turned away who has no funds. Discussion groups have strong leadership as it was felt by Detrich that it was needed in that these persons were immature babies. ${ }^{1}$ Discussions sometimes get heated, but anything goes short of violence. Success of Synanon's Methods

There are no professionals hired. This was repeated over and over in the discussion which lasted until midnight, that "professionals" would only mess things up from a cook on. They had not experienced what synanon training was and could not rightly help or be of help. The whole idea is to let them--men and women--do their own work as part of their treatment in becoming responsible persons--again reality therapy, but without professionals at all. This institution is the one with no professional help. This makes the group need to develop its own workers in order to grow. Folk come to synanon and make it their home for as long a.s four years. To date 750 have "graduated," but many have stayed with the organization, which has grown to size in a commercial way to help support itself.

$I_{\text {Tommy Duncan, Understanding and Helping the Narcotic }}$ Addict, Prentice-Hall, Inc., Englewood Cliffs, N.J., 1965. 
Again, it was stressed "we know how to treat arug addicts successfully and we want to be self-supporting as that is the way to do it." Even though visitors tried to express feeling that if they had such a good thing going, why not extend themselves and train people who were professionals to work synanon's methods. Again Kline was emphatic in a "no." Why not take government aid? Again, he volced the view of Synanon that they know how. to cure drug addicts and they wanted no strings attached. Mr. Kline, himself a graduate of Synanon from addict of seven years, is a polished gentleman who is now working in a jewelry store. He had been thought hopeless, he said. He'd been in and out of Lexington prison. When asked if he had experienced any trouble in finding a job, he said he had not, but that people had taken him at face value and trusted himin a business like jewelry where the pattern for most addicts has been one of stealing to get money for drugs. He said he had no desire for drugs, but did keep away from them and from liquor for he felt it could be a temptation again. He wasn't real sure he could withstand the temptation.

Synanon Businesses

However, many adicts stay with the group and work now in Texaco Gas stations which synanon has leased in California. They started with one gas station, called 
Seaside gas and the Texico folk were so impressed with the operation of this station, they begged synanon to lease their stations. Now trainees for Texaco stations are sent for training to synanon run stations. Until just recently the Detroit Synanon was only for a business of selling advertising gimics such as pens, but the need for a treatment center became so acute that 1t was opened at 8344 East Jefferson Street, Detroit, Michigan.

They also have a large scale clothing business and just recently organized a jazz band which will make a recording, and appear as "Sounds of Synanon" to college campuses to play for dances and also to hold seminars and discussion groups.

A sixty-two unit apartment building has been purchased in Santa Monica costing $\$ 700,000$. It consists of from one room to large three bedroom apartments with two baths. The Cloverfield apartments are to house a staff and Synanon residents. There are patios and terraces--all very plush.

Synanon is on the air in Berkeley California as well as a first fair at Seawall San Francisco. They also have a theater in San Diego. Synanon is big business and out to show the world that they are terrifically proud of their acievements and want no help from anyone, although huge donations without strings 
have been accepted as the house at Tannerville, New York. I Detrick Has no Use for Religion

Chuck Detrick has no use for religion and some of his first house guests when he was just getting started by entertaining along with arug addicts some AAA members who wanted religion. He didn't want religion. He said "they were too preoccupied with salvation, spiritualism and God." I was trying to run Synanon as a social scientist and psychiatrist would. I didn't like the religious overtones. I felt that Synanon didn't need serenity; we had too much work to do. So I told the alcoholics to get lost.2 Bring about moral regeneration through the process of education. "It is not that we teach anything," said Detrich, "but people in the program learn something. AII we try to do is provide a situation in which people can learn to live." 3

As of May 1967 there were 456 men, 205 women, 97 children in residences of Synanon, making a total of 753 or an increase of 29\% over the May 15, 1966 figure of 584. It takes $\$ 60,000$ to $\$ 70,000$ a month, to run all these houses.

Isynopsis, A Newsletter of Synanon Foundation, Inc., June, 1967, p. 1-8.

2Robert A Zimmerman, "Synanon, State Seek Same Goals," The San Diego Union, January 9, 1964, p. 24.

3 Ibid., p. 24. 
Synanon Wants No Government Help

Walker Wilson, writer of social issues has lived at Synanon in order to learn its methods. He expresses the fear that the organizations who are taking on Synanon's methods will become but that in name and that the old prison keepers of the penal type thinking will eventually take over just as they did after Dorothy Dix's valiant effortg toward Mental Health reform or those of Clifford Beers. This is why, he says, Detrick is so determined to run things without government intervention or funds for he feels that the old philosophy that is so prevalent, "once an addict, always an addict" would again be brought over by those who have failed so miserable in their treatment of addicts in such institutions the government has formed. Employees from these institutions would be hired and soon it would have no resemblance to synanon methods even if it had started that way. They are not too happy to share their "graduates" with other groups and would rather keep them to build up the true synanon. 1

IWalker Winslow, "A Lesson from History," Los Angeles, I962, p. $1-8$. 
Daytop V1Ilage

History and Location

Daytop Village is located far out on Staten Island at 450 Bayview Avenue, New York. The sprawling, lelsurely looking frame house with ten acres of roaming space skirting a bay gives a relaxed feeling that was further felt by the worker who visited this institution on two occasions. The first visit was June 8 and the second on July 7 th 1967 . The reason for return was to hear a sroup seminar in session.

In 1963, a treatment facility opened in another building, known as Daytop Lodge, located about a mile from the present treatment center. It is now closed. It housed only twenty-five men and was also for research supported by the National Institute of Mental Hygiene established by the Supreme Court Probation Department, Brooklyn New York. The need was felt for a facility to house more persons, including women. Formerly, only court referrals were residents. It was the goal to have a place where those plus voluntary residents might come. 1

So Daytop Village came into being in 1965. It too has a grant from the National Institute of Mental

IDaniel Casriel, M.D. "New Success in Cure of Narcotic Addicts," The Physician's Panoramo, October, 1966, p. I. 
Health, gets money from the Community Health Board of New York City and from donations and foundations. AIso there is a contract to provide services for westchester County, New York. A similar institution, also called Daytop Village is located 135 miles away at Swan Lake, New York. The Staten Island facility has space for 100,1 but on June 8, 1967 had 85 persons in residence. Swan Lake's Daytop Village had 90 at that time, according to informatant, Charles Devlin or Daytop Village Staten Island.

\section{A Three Phase Program}

The program is geared to three phases, Mr. Devlin stated. The person comes in off the street, voluntarily or by court order and the proportion now is about half and half. He usually has no intentions of staying any length of time, just enough to get feeling better or as a refuge as he needs a home. He is not babied during his withdrawal which becomes much lighter than for those in jail because of the therapeutic atmosphere here. In jail if he cried and complained enough he would hope to get demerol or sympathy. But here status is gained by taking it manfully. He is chagrined to think he can't take it when a slip of a girl comes over to his davenport

${ }^{1}$ Deymour Shubin, "Therapeutic Village," SK \& F Psychiatric Reporter, March-April, 1967, p. 2. 
in the living room and says, "What's the matter with you? I was there last week and it wasn't that bad." His contacts with family are cut off for at least two months. His relatives are asked to not open any mail he might send and to shut the door on him if he comes home. He is not to be reminded of the past. It is several months before he can get a pass to leave and go to town. Then he must ask the head of the house, as a paternalistic figure for walking around money, and permission to go.

He gets this privilege only as he does his assignments well. After the "honeymoon" is over--the withdrawal, he is given the lowest of tasks to do as the kitchen or cleaning the rest rooms. But as he does those well, he is given more responsible jobs. This state of working in the house is of a year as stage one. Then it is hoped that the next year can see them living outside the house but working yet at Daytop. Then the third year he is not directly involved in the program, unless he chooses to. stay with the program as staff. However, he can return once a week if he chooses for counsel or to take part in social or therapeutic sessions. He is then a working member of the community, an ex-addict who now is a missionary for the cause. I

I Shubin op. cit. p. I-3. 


\section{Span Program}

As a "missionary" he may be a member of a group called "Span Special Program Against Narcotics," which goes into neighborhoods with the largest drug problem to try to stir up interest in getting addicts to come to Daytop for treatment. They talk to them to see if the addicts mean business as admittance to Daytop is not the easiest for voluntary residents. They are probabiy asked to call several times for an appointment to test their sincerity. ${ }^{I}$ Most of the residents are heroin addicts, but not all. .

Other ex-addicts are being employed with open arms by the new city programs in neighborhood centers of which there are now seven ${ }^{2}$ but it is hoped that there will be forty-five held in old store fron locations. An induction center, Rizer's Island prison 3 as well as Hart Island Community Center are also hiring these "graduates" and finding them most useful in setting programs into operation similar to Daytop. 4 so the

$$
\text { Iop.cit. p. } 3 \text {. }
$$

2 Flyer by the Narcotic Addiction Control Commission, Albany, New York.

3 Phone conversation, July 7, 1967, Mrs. Nancy Hoving, Assistant to Dr. Ramariz.

${ }^{4}$ Conversation with Dr. Jack Davis, psychiatrist Hart Island Community Center, June 8, 1967. 
worth of Daytop's program cannot be measured soley by the number of "cured" addicts. It is hoped that each ex-addict will be able to reach others and thus help in prevention as well by talking to youth to keep them from ever starting on drugs. 1

\section{Marathons}

The value of Daytop Village is also in the training of professionals who may come to live at the institution for four days and enter into its activities. This may mean a new reevaluation of himself as a person. AIso there are 20- -40 marathons held for addicts and for such persons who wish to help addicts. In this long session the defenses are broken down, says Mr. Devlin. Then the person will finolly break down and tell everything that is bothering him. He feels these are of great advantage. They are help once a month. The person is allowed to only an hour and eat as needed. He is not to talk outside the group. 2

Personnel at Daytop

The Executive Director is Mr. David Deitch, a former Synanon "graduate." Two more, names unknown, were brought from Synanon to head the program. Dr. Daniel Casriel, M.D. former court psychiatrist, but now with

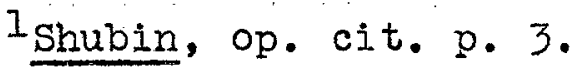

2 Casriel op. cit. p. 2.
} 
a private practice is the medical superintendent. None of these persons were seen by the writer. The feeling is that they are mainly just faciliators like others: in the program who have gone to the top as Mr. Charles Devlin. Mr. Devin explained he had been an addict for nine years and been with Daytop and now as a graduate was in an executive position. It was he the writer referred to as having given information. He plans to leave in the fall to go to college, however. One would never know his background as he seemed very efficient and a well organized young man. ${ }^{I}$

The treatment for character disorders such as drug addiction has lagged far behind care of neurotic or psychotic patients. The psychiatrist has usually been aware of the fact that his methods did not work, so excused himself and sent his patients off to Lexington or Fort Worth hoping they could do some good. But they too have little success. Some professionals have used methodone to cure heroin addiction as heroin was used to cure morphine and another vicious circle was formed. Stricter laws were enacted and long prison sentences with these institutions bulging with addicts as mute testimony to society's failure to cure them ${ }^{2}$

\section{Ibid.}

2 Ibid. 
Philosophy of Daytop

\section{Success of the Program}

Noyles and Kolk even went so far as to say that "group psychotherapy is not successful."I so for thirty years theories, modified, reformulated and rephrased have failed to help. But after thirty years of such darkness, a treatment was stumbled upon before it was known why it should be helpful. Dr. Casriel had observed the methods of synanon for four years. Daytop greatly modified the program by the successful amalgamation between the professional and non-professional in a therapeutic climate which appears to be very promising of probable rehabilitation and possible even cure of the addlet on an effective, efficient, inexpensive basis.2

The non-professional's attitude toward the success of the program is, Dr. Casriel says, "that there is the absence of the previously held attitudes toward the addict which were either all permissive or all punishing. In contrast, Daytop's attitude is one of responsible concem, which may be expressed by a dressing down rather than a pat on the back. Daytop challenges the addict to stand on his own feet, rather than permitting him to

$$
\begin{aligned}
& \text { Iop. cit. p. } 3 . \\
& \text { 2casriel op. cit. }
\end{aligned}
$$


lie back and walt for others to do everything for himl Adaptive Psychodynamic Theory Uses

Explaining the professional rational for why the program is working, Dr. Casriel says that Adaptive Psychodynamies Theory is used. He says that "this theory as well as Freudian Psychodynamics state that the basic motivational forces of human behavior are purposeful and goal directed. In general, behavior is designed to avold pain and gain pleasure. The adaptive response in situations of danger (which is the anticipation of pain) is either flight and or fight." 2

Dr. Casriel modifies the adaptive psychodynamics theory to say "that in addition to fight and flight, there is a third, perhaps more primary mechanism in which one avoids danger or pain. It may be called detachment, using the non-painful" emotion of withdrawal. Just as a turtle puts his head into a shell, so do some people witharaw from the pain of awareness, what they experience as the danger of everyday functioning, by withdrawing into themselves. Those people whose primary mechanism of defense is detachment are those who fit into the psychiatric classification of Character Disorder. 3

I Ibid.

2Ibid.

3 Ibid. 
"By successfully removing themselves from the pain of reacting to stress," he goes on to say, "they have detached themselves and spend their energy reinforcing, by encapsulating, their isolation to a non-painful state of functioning."I

"Thus the patient," he says, "takes flight without fear into a fortress in. which he feels secure, but in which he is quite isolated, incapacitated in.imprisoned. The longer the individual stays inthis ow jail, the thicker the walls become by secondary encapsulation, with the result that the individual is less and less able to cope with the problems of everyday living:?

Dr. Casriel says "that once this has happened the standard techniques of using introspection and observation are useless. The individual patient, though he hears, cannot be reached. Though he knows, he will not change." 3

He says, "the incapsulative shell can be made out of alcohol, drugs, narcotics, homosexuality, delinquency, or just quiet emotional detachment from all meaningful relationships without necessarily being asocial. or antisocial. As a matter of fact, encapsulation could be

\section{Ib1d. \\ 2 Ibid. \\ 3 Ibid.}


socially productive--the shell can be reading in the library every spare minute, up in the attic with a stamp collection, down in the cellar with the tool chest, etc... If we forcefuliy remove one means of encapsulation such as narcotics, the individual will seek a substitute encapsulation such as alcohol or drugs."I "Feelings," he says, "such as fear, anger, guilt, and depression are painful to experience and therefore motivate the affected person to attempt to ameliorate the pain. These feelings may become so painful that they may prevent the neurotic person from functioning; but even if rendered helpless the person remains in tremendous pain."2

"On the other hand," he says, "people classified as character disorders are usually suffering no intense pain even though their functioning in many areas is defective, deficient, or absent."

The doctor says, "a human personality, like a flower, cannot grow in a closed box. When an individual utilizes withdrawal early in life, or even later in life, his personality and character stops growing, regresses and atrophies." 3

${ }^{1}$ Ibid.

2 Ibid.

I Ibid. 
Taught to Grow Up

So to help this person, the shell must be removed and the person not allowed to return by acquiring a new encapsulating shell. When exposed to "the light of reality, he is powerless to isolate himself without his fortress prison, he is in position to be taught how to grow up," Casriel says. 1

For the off-the-street addict a full time therapeutic institution is needed to enable him to grow up and develop emotionally, socially, culturally, sexually, vocationally, and educationally. "This is no small undertaking, Cr. Casriel admits," but nothing less will suffice. These principles underline our efforts and our treatment techniques at Daytop."2

"Empirical observation and research at Daytop has found that there are only two prescriptions needed for adequate treatment. (1) No physical violence, (2) No narcotics or other chemicals, and by inference no other shells under which to hide. By these two simple prohibitions we have successfully eliminated fight and witharawal, two of the ways an individual uses to cope with pain and danger. There is only one mechanism of defenge which we can utilize, and that is reacting to

\section{Ibid.}

Irid. 
real and imagined stresses and straing, real and imagined pains and dengers by fear."

"Motivated by fear, the addict can do one of two things," Dr. CasrieI says; "He can stay at Daytop and attempt to cope with his fears, or he can mun out the door. By our records over the past 18 months we anticipate that $84 \%$ of those who stay at Daytop for one month will sooner or later remain to get well. Sixty percent of all entries stay. We do not know what happens to the other 40, percent who will never return."?

Why do addicts stay? Dr. Casriel explains "that It is the overwhelming identification on the part of the entering addict, and genuine concern and responsible love on the part of the members: 3

Initiating Treatment

In the first few days are crucial. As explained the addict has only planned to stay a few days until he gets feeling strong enough. It seems the other residents read his mind, Dr. Casriel says, for they have gone through the same phase. They laugh at him for thinking he in his babyhood can walk again so soon out in the open world of drugs. He thinks they are getting drugs somewhere to be functioning so well and feels he is

$$
\begin{aligned}
& I_{\text {Ibid }} \\
& { }^{2} \text { Ibid } \\
& \text { Ibid. }
\end{aligned}
$$


being tricked. They tell him to walt until the "three month depression sets in." $\mathrm{He}$ is curious as to what they mean. He finally realizes the old members are off drugs and are really as happy and as well as they look. I

He has a new awareness and wonders what this program is all about and he asks questions and starts to cooperate. He goes to work. In small group sessions of ten members, called encounters, he with those who have been in treatment longer than he discusses present problems of his work. They are held for ninety minutes, three times a week. He learns to think and speak his mind in planned seminars and as the writer observed in public speaking periods.

\section{D1scussion Groups Visited}

The writer observed one of these public speaking and whole group discussions held for an hour--1:002:00 on July 7, 1967. Resident Tom Macher was in charge. He sat in front of the group in a pleasant room filled with chairs. No professional person was on hand. He simply told of his experience of having taken some money in order to buy cigarettes. He had been demoted in his job. But by this humbling experience he had learned that he must become still more responsible. He felt remorse for having done it, not so much for the

$$
{ }^{1} \text { op. cit., p. 2-6. }
$$


small amount of money taken, but for what it represented to him of still immaturity. He explained to the writer later that he felt justified in having the money as he had earned it, but that because of shortage of money, it was not given to him. He said on the outside he had had all he wanted of money, cars and girls, but not learned to grow up to assume the responsibility such privilege entail. He felt that many were not from the slum as is often thought, but that the group contained many "poor little rich boys."

As a response to his confessional to the group, others started telling of the "traps" as they kept alluding to that they had gotten into. Not knowing what these were and the individual did not state as evidently the group knew, it helped others to express themselves. One girl wore a large sign covering her and dangling from her neck, saying "after 5 months I didn't turn off the lights." A young boy, perhaps fourteen also held such a dunce cap idea sign around his neck with something he'd done amiss. The writer could not see just what it read. But she was told that like the stolen money, it represented more than it appeared as only something trivial.

The group were dead earnest, not a sign of triviality or laughter was noted. However, they seemed to be striving for something thèy could not grasp. The 
wrlter feeling it was "God" they really were struggling to find asked the speaker after the meeting what his religious background was and if he felt this type of experience meant anything to him rellgiously. He said he was a Catholic and that to him this was religious-his being honest with himself. Honesty Implanted in Growing Up Process

This honesty factor is strongly fixed by the time the resident has become "staff." On the first visit the writer was waiting to see Mr. Devin, another young man, Mr. Kenneth Williams, just under him in position was sent to talk with her and began by saying that she should not write down anything until Mr. Devlin came, as perhaps the information given would not be what should be circulated. The writer, however, found the material so interesting and so distant to the thinking of other places. visited that she could not resist jotting down notes. He reprimanded her several times but the urge was too great. Finally, he got quite irrate and so the writer said, "O.K., I give up, I guess I was born with a pencil in my hand," and tossed the pen over to him. Upon Mr. Devlin's arrival the writer told him of the experience and asked if anything he might have said was not for circulation. He said that his underling was a little rigid having 
learned the hard way, possibly, and that the material given was correct and not censored!

Family Living Teaches Responsibility

The group went about living like any big family. When special problems do come up a special encounter may be called. The groups are shifted around and the decision of gho is in what group is the responsibility of such persons as Mr. Deitch, Mr. Devin, and Mr. Williams. They are also in charge of assiening jobs and promotions. They face reality situations of the here and now and not what they had as problems as children. Cr. William Glasser's book, Reality Therapy was mentioned as being similar in approach. It was agreed expect that there was no professional therapist to direct the groups, but a leader did emerge. No doubt, leader figures were purposely sprinkled among the groups to facilitate getting the talking to flow. The writer regretted not being able to stay longer to take in these various treatment methods. Ninety Day Hump

As alluded to the addict again undergoes a critical time as he reaches about three months of the treatment program, for it takes about that long before he comes to a critical awareness of himself and this is painful. Many want to leave. They learn their manipulative be- 
havior does not work. They realize how irresponsible they really are and what a mess they have made of their lives, Dr. Casriel says. 1

"As the repressed and unconscious feelings become conscious, the pain of depression, the panic of fear, and the dread of strong guilt of greater or lesser intensity develops. Some awaken with frequent repetitive nightmares, just as people who are in concentration camps develop nightmares after they are freed from their imprisonment. Those who do not leave Daytop are usually pleading to return within a week. On leaving, they may again take the narcotic way into a worlo of insensitivity to pain, but to their great surprise and panic they find the drugs no longer effective in the same way. They have become too aware of the real world to be lulled into a false sense of security by heroin. It is only through the constant understanding and support and examples in the environment that the members are able to weather the emotional storm."2

Dr. Casriel continues, "Thus at Daytop, the addicts find they are living through emotional pain they once thought impossible to bear without drugs. And they live through it without the help of drugs, alcohol,

IWilliam Glasser, Reality Therapy, Harper and Row, 1965. 2 op. cit., p. 6. 
narcotics, or even tranquilizers." 1

\section{A New Awareness}

After this stage he says to himself, "I am able to live in the stream of life without pilis or narcotics." This new awareness along with the encouragement from the older residents that "this too will pass" and the new awareness he gradually comes our of his depression. ${ }^{2}$

Now he begins to evaluate everything for himself in search of the truth about his feelings. This is called "gut level" truth at Daytop meaning the purely emotional resonant, honest feelings that are comparable with those of people in analysis who have finally felt their visceral affective feelings. He is no longer afraid to face himself. 3

"This stage appears to last for about a year. During this time he is emotionally maturing. He has found a purpose and a positive direction in life. He reports his subjective feelings and attitudes, which he realizes are immature." 4 The observer noted that only

$$
\begin{aligned}
& \text { 1op. cit. p. } 6 . \\
& \text { 2op. cit. p. } 6 . \\
& \text { 3op. cit. p. } 6 . \\
& \text { 4op. cit. p. } 6 .
\end{aligned}
$$


a few took part in the discussion. The talk was very low and was heard only by strainging. It seemed to be hard to speair the truth about one's self. There seemed a rather depressed atmosphere. Others of the group were rather apathetic and one man near the writer kept asking someone what time it was and seemed anxious to "get out of here." Not all had reached this phase of wanting to analyze themselves, it appeared and they would rather still stay in a shell.

Now he becomes objectively critical of his own performance, says Dr. Casriel and to feel that more responsible jobs offered to him, once thought beneath him are now invisioned as too much for ability which he thinks he has. These feelings of unworthiness and inadequacy are attached in and out of encounters as being neurotic. 1 New Personality Tomerging

So this goes on for another year and by the end of 18 to 24 months a new personality has emerged, one very different from the incoming adaict. He can stay and receive more education for administrative and teaching responsibilities or leave as explainea. He need not take a job having to do with drug addiction, but many are encouraged to do so. If he stays for more training he

IThe Ethic,- Vol. I, No. 63. New York, Daytop Village Inc., 1 January, 1967. 
is given it in administration, direct inter--intracommunity relations, vocational training, job placement, and responsibility for teams of people. It was learned that work towards high school equivalency was given, and special reading help. It is an annex of Public School 203.

Leisure Time

The Iife at Daytop is not all serious as the fellows like to get out and play football. The group was lounging around the evening of the writer's first visit. The coffee pot was available and groups were leisurely talking. Another group were having fun in the kitchen, evidently after supper, making pizza. Every other Saturday night there is a party.

There are no locks at Daytop and he is free to leave. It is hoped that the watchwords: honesty, reliability, and responsibility will become a part of their lives so that they can become functioning useful citizens. 1

IPublic Health Service PHS World, U.S. Department of Health, Education, and Welfare, Vol. i, No. 4, April 1966. A reprint; page unknown. 
Exodus House

Personnel and Program

The Exodus House is 10 cated at 306 East 103 rd Street, New York. This is in one of the highest drug addiction areas of the city of New York. It has been formerly a part of the East Harlem Protestant Parish, started in 1958. Recently Exodus House, Incorporated, is on its own, according to Miss Evelyn Jaburek secretary of Exodus House. Because of the many duties of the directors, the writer was only able to meet Rev. Stephen Chinlund and Rev. Iynn Hagman. Others of the staff, Mr. Larry Ientchener was also met. He heads the shop program. They have a consulting psychiatrist on the staff. Wr. Beymour Eidale is their research sociologist who has written a book, Portraits from a shooting Gallery being published by Harper--Row and to be out by September 1967. This is a book on research on addiction. However in mimeographed form much material of his writing is available and was given to the writer. Ex-addicts are also on the staff to lead in the discussion groups which were assembling on the morning of July 7, 1967 when the writer visited. Because of the already over-crowding, she was not permitted to visit. Last year three levels of counseling groups were formed, but now allowing for more individualization 
six levels are held according to Miss Jaburek. These are held each morning for six days a week for an hour a session. Such things are discussed as "what did you do last night?" or "what bothered you?". Particularly If the person went back to dope, these questions are directed to the offenders. This type of present day, reality counseling as described by Dr. William Glasserl is used with a leader according to his plan.

After the therapy session the men are to 80 to shops. A pre-show experience was more for therapy than for learning a skill, but it served both well. Mr. Ientchener explained that across the street at their shops they made picture frames and small items in the $A$ shop and were paid ${ }^{\prime} I$ a day. Then later in the $B$ shop they were paid 1 an hour and made custom items as cab1nets. There are pottery and glass blowing shops.

The day program lasts from 9:00 A.M. until 5:00, including group therapy and the shop training. Then the men have a discussion group on Thursday nights from 8:30 until 10:00. The discussion is not related to drugs and is chosen by the men. (this is a men's only program). Some current topic as "Is Civil Rights Fading Out?" which was discussed on July 6, 1967 is typical. It helps the men learn to become involved in real iffe and to make use of their expanding interests and abilities as learned in the counseling. An addict is chosen to 
lead the group.

Residence Quarters to be Occupied in Fall of 1967

As this present program is limited in not having the men for residence, a new building is being built across the street for this purpose and for staff quarters. The present builaing is anything from fancy, but in being run down is probably much more acceptable to the type of men who come in and feel at home in this atmosphere. The men were browsing around drinking coffee when the writer arrived. They were then waiting their therapy groups. Presently they are dealing with about $45 \mathrm{men}$ which is twice the amount a year a.go. It is planned that the new facility will be used for men who have been in the program for a Iong enough time to see they are good prospects and not just off the street, looking for a free bed and meals. There will be space for twenty-six men who will stay for three months and then are to return home, but still be with the program. This is a venture of faith with private donations. The men, it was said, could get on city welfare being called "handicapped." It was not ascertained if the person receivine such money would pay for his care through this means.

It is felt with this 24 hour a day approach, the work will be more effective. There is also voluntary classwork for two hours a day in mathematics, reading, 
and English. They may work toward a high school equivalency, Miss Jaburek stated.

\section{Volunteer Program}

Most of the men come voluntarily. It was found that men referred by the welfare or some agency rarely stayed with the program which lasts for two years. However, according to Miss Jaburek (who gave all the information, except where mentioned), no one has lasted over sixteen months. They must be detoxified before coming and there is screening done to find if the men are really sincere in wanting to be cured. Needs of the Program and the Effectiveness of It

Miss Jaburek stated that they needed more clerical staff as the record keeping was getting too much with twice as many men in the program. They also need money, space, and group leaders. Miss Jaburek could give no statistics as to the effectiveness of their program. However, a nurse tests the urine to see if the men who are still coming are not using drugs. This is cone three times a week. It is expected that men stay off drugs while on the program. Vocational Rehabilitation

They feel particularly fortunate to have been chosen by the Vocational Rehabilitation to furnish men for their program. It was stated that if a man had the capacities they would go along with as expensive 
a training as for a physician. This is purely hypothetical as no one has yet tried it. But this is putting men back into the labor market. I

As the last step in treatment the man is placed on a job. There is follow-up on this placement. He may still keep in touch with the program of the House. 2 It is felt that to have the center in the neighborhood of highest dmag use is of great value "because ghetto addicts are not easily amenable to" geographical cures, (going from the scene of addiction to avoid the temptations of drug use.) They can always come back and if they are not well defended, if they have not utilized therapy to solve the real home problems as they encounter them, then they are not going to be well and stay well when they come back to the old environment. 3

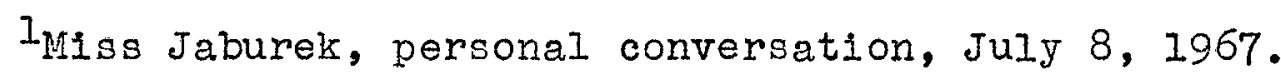

2"Exodus House: Past Present and Future," no author listed, August, 1966, New York. P. 3.

3 Ibid., p. 3 . 
Religion Not Primarily Evankelically Orientated

On Sunday a minimum of Bible study is given geared to looking at problems of life as pertains to the men. It is not compulsory. It is not of the evangelical, soul-winning nature, according to Miss Jaburek.

A movie has been made of their work, "The way Out." This is now being shown.

East Harlem Protestant Parish--Parent Organization

This "child" of East Harlem Protestant Parish has been ministering to addicted persons since 1950, but the formal Narcotics, Commission was not formed until 1956. The committee includes professionals as: a lawyer, a psychiatrist, a sociologist, a hospital referral worker and others. Not all hold the same religious views who are on the committee. I

The views of the committee are:

We affirm that addiction to heroin is in the same category as other addictions, and that all represent varying degrees of rebellion against God. Heroin addiction does not kill the moral sensitivities of the addict, although desire for it almost entirely eliminates a sense of moral responsibility when the craving for narcotics is upon him. Even the most confirmed addict, however, shows evidence of his moral nature, in that he has his own "commandments" of things which he will not do to obtain heroin even when in direst need. Spiritually, addicted people are empty, and they know that they are empty. After the first happy days of addiction are over, despair and meaninglessness press in

$I_{\text {Tommy Duncan, Understanding and Helping the Narcotic }}$ Addict, Prent1ce-Hall, Inc. Englewood Cliffs, N.J., 1965, p. 120 . 
upon them, offering them no hope. For a small number, rebirth in God has revolutionized their entire personalities, and they have found purpose in life without narcotics. These rebirths point to the possibility of all types of addicted people finding new life in giving their lives to God. 1

The services are free to all who wish to come. Some have been helped by this parent organization as many as ten years.?

\section{Green Haven Prison}

Program of Exodus House

Another arm of service of Exodus house is work at Green Haven Prison. Rev. Chinlund goes each Thursday to conduct group sessions. This is voluntary on the part of the prisoners, who have committed narcotics crimes.

"By holding the adaict responsible for all his activities, we can place the burdens of his Iife squarely on his shoulders. We begin by helping the inmate recognize that there are problems behind his pattern of adiction. He must bome to recognize that he is sick, that his addiction. is not an accident nor the result of circumstances in which he has played no part. We

Norman Eddy, unpublished paper, "A Christian View of Addicts to Narcotics,"N.Y., 1963.

Duncan, op. cit. I2I. 
also help him see that his sickness is in no way responsible for breaking the law. He is, in fact, medically and legally sane and cannot justify his crimes on the basis of his mental condition."I

A large orientation group of twenty called the "C" group meets once a week under the leadership of rehabilitated ex-adicts. In time it is hoped that this group can be run and organized by inmates and officers themselves. It is felt that if a person is given the opportunity to help someone else he becomes stronger in his own rehabilitation. Also it is felt that the inmates will accept the facts of their own cowardice in regards to drug abuse if it comes from other inmates. 2

"The ex-addicts presiding over the "C" groups w1ll also lead a "B" group once a week. They are more intensively therapeutic in purpose and discussion is centered around those problems emerging in " $C$ " group that existed before a man became addicted or behind his continuing addiction. Our objective in the "B" groups is to raise the level of awareness to achieve attitudinal

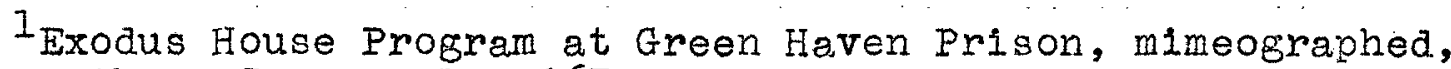
no author, January $1,1967, \mathrm{p} .1$.

2Ib1d., p. 2 . 
changes necessary for the person's total rehabilitation. These groups prepare the addict for entrance into an "A" group, where we have available professional direction of intensive group psychotherapy right within the prison walls."I

"Even though the Exodus House staff will always have direct responsibility for the total program in prison, it is hoped that increasingly the men with whom we are working will take responsibility for participation in discussions." 2

"Eventually, those members of 'A' group who are considered ready, might be co-leaders of $C$ or even $B$ groups. In this way, they can make firmer their own progress as well as bring a particularly sharp note of relevance to the meetings." 3

"There is also a training program for custocial officers, guidance officers and parole officers. It covers the following material: narcotics. Iaw, pharmacology of most commonly abused drugs, psychopathology of drug addicts, program in prison, program in Exodus House, programs in other places, clinical practices of conducting

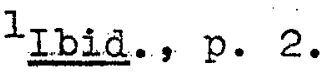

I.bid., p. 2 .

3 Ibid. , p. 3 .
} 
groups." "I

Hart. Island Community Center Location and Personnel.

Hart Island Community Center is off City Island, the Bronx, New York. Situated in peaceful surroundings it gives a leisurely atmosphere of relaxation. There are several acres of grassland. so different from the environment of some of the centers. A ferry takes persons to the island.

Dr. Jack Davis, psychiatrist is the medical director and gave information to the writer. There is a director, who is an ex-drug addict. His name was not learned. Several ex-addicts help with the program as leaders. They are Daytop or Synanon graduates.

Father Daniel Egan was at the center the first visit on June 8th. However, by July 7 th he had left to make a movie from his book, The Junkie Priest. It was not known whether he was to return or just what his position was with the group--voluntary or paid. He had intimated however, in conversation and so had Dr. Davis that he would be working with the group trying to work out a religion for Jews, Protestants and Catholics using the Catholic chapel and wearing the vestments of his faith. He was a personable man, not dressed in

\footnotetext{
${ }^{I_{\text {Ibid. }}, \mathrm{p} .} 3$.
} 
vestments, but very ordinary sport clothing at the time of the visit. The writer was shown about the institution by him and invited to eat with him at the cafeteria and then he suggested she might wish: to speak to some of the boys. No distinction was made in rank from addict to Dr. Davis or priest in what fare of food--which was served rather informally. This pattern gave indication of what the fellows did express that "we don't need the professionals." We like Dr. Davis, but don't need him. He is unusual in that he (as well as Father Egan) are "taken apart" during therapy sessions as much as the rest. Dr. Davis is a psychoanalysist, but said he does not that approach. It tended more to reality therapy as mentioned in groups from which they are patterning their work having "graduates" from these institutions. So they too have group therapy, however with more leadership as Dr. Glasser would have used. Father Egan showed the writer a blackboard upon which was. written, "a man's worst difficulty begins when he is able to do as he likes," by Thomas Huxley. As the writer was too late to hear what was discussed, it can only be left to the imagination. But Father Egan said something provocative like this was used three times a week, Monday and Wednesday and Friday mornings. On Tuesdays and Thursdays they have group encounters to air hostilitieg. On Friday night a seminar is held on 
a topic of interest and led by various of the men. The topic is not about drugs, but something of current events perhaps. Men come already detoxified from such places as Manhattan General Hospital. Those in jail may choose to come to this institution. The program is at least for two years, but no fixed time. As the sentences for those in jail is three years, it would seem that the program must extend for them. This institution had only started three weeks before the writer's first visit which would have been in mid May, so really not much could be known as for results. Only twenty men were there and upon return a month later no more had been sent, but they expect to eventually take a thousand at this old prison site. No women are accepted so far, but it is planned that there will be women later. However, there were some staff wives and clerical help who were women. They hoped to find a trained social worker and hoped she would come the following day, hoping she would take the position. She would select her staff who might some be women. Here again some of the men expressed their opinions that they did not need a social worker. The writer felt he was a little shortsighted and in fact about the need for any of the professional staff as it is felt that they will give educated direction, although Dr. Davis had not worked with addicts, before and was just seeming one with them so far. 
So far the residents were all voluntary patients. Much more trouble is expected when the patients come by court order from prison. The men have various jobs around the institution and are taking pride that it is their home. One man expressed the hope that someone was to bring them bedspreads. They seem satisfied to call it home and in talking with several of the men, it appears they have pushed family problems their wives may be having aside thinking they need no social worker. One man said, "see the boys playing ball; if they are functioning that well they can take care of their own problems." It was probably very short-sighted and showing that men who had been in the institution such a short time were only beginning with thoughts of personal responsibility. It had not gone deep enough to make them think of their wives and children whom they probsbly were pretty much forgot during the time of addiction anyway. Their attitude was that the welfare was taking care of them. It was learned that Father Egan had been doing some gocial work with families of the men. They figured since he had left, his job was not needed.

\section{The Haven}

Dr. William R. Baird, who operates The Haven is a fuli time physician with practice on 8605 th Avenue, New York City... After closing time at 8:00 he tries to 
get in some of the best $T . V$. or radio listening time for teen-agers to speak regarding prevention of drug taking. Or he might speak at some school or other group. Formerly a T.V. actor, he is well equipped for this and has been on some national hook-ups when interviewed by popular T.V. stars.

Then at 10:00, Monday through Thursảay he opens a free clinic for drug addicts at 222 ll6th street. This keeps open until three or four A.M. However, this summer, the program was just too much, so this was being omitted temporarily. On Friday nights the Haven, next door at 226 116th street opens its doors from 10:00 until perhaps three or four A.M. This is a group discussion lead by the doctor. Addicts must be accompanied by a relative or guardian.

The writer went past The Haven, but as it was not in session in the summer, could not see $1 \mathrm{t}$ in operation. Dr. Baira, being busy was not available for discussion, but his wife and office receptionist at both his practices gave the writer information desired. She said the doctor used no drug for withdrawal, but tells them to reduce the amount of heroin taken. "I tell them to take a knife and just scrape off some of the heroin form the spoon, a little more each day." She says that the problem is mainly in the mind and 
the physical addiction is not the main problem.

The patient is screened before acceptance into the program to see his real motivation and desire to change for good. The doctor uses plain talk, mincing no words with those who are not sincere or want an easy way out. Having worked with adicts on and off for dozen years and having the clinic open for four years he is well aware of all the angles. However, he gauges his remarks to the person and can be coaxing and soft when needed, depending upon the person. As the persons raise questions he talks to them about their problem. Those who have been off the habit for some time come to support him in "testimonials" whenever he asks them to come. Th1s gives the others courage that they too can kick the habit. The counseling goes on from 10:00 until the wee hours and then after three or four A.M. he may work with individuals in the other office as on the other four nights

\section{Individual Treatment}

Individual treatment might consist of some medications the doctor has found useful. Mrs. Baird did not know what was used and intimated it was pretty involved. As some are run down multiple vitamins are prescribed in

IFrancis A. Soper, "Doctor With a Heart," Listen, June 1966, VoI. 19, No. 6., p. 10-13. 
some cases hormones. He advocates a good well-rounded diet of just good plain food. He himself uses no stimulants as tea or coffee, nor does he smoke or drink. It is not known if he advises this program for his patients. He himself is a model of physical fitness, finding time in all this program to exercise in a basement bym or parallel bars in his yard. Need for a Residence Hospital

But he is far from satisfied with his results. After a person is accepted for treatment and is usually kept on for a year seeing the doctor each Friday night and as often as the doctor feels it is necessary during the week to come or call. But he would like to have them in residence at a hospital where they can be better controlled. This $\$ 10$ million dollar dream is a long ways off financially. Here male attendants would be used. He thinks the patients should be in treatment for a year. It was not learned just what would be involved in the treatment other than what is done now, but the doctor no doubt, has definate ideas. With the backing he has of mayor and a sizable list people of note on his board of directors, advisory board, etc., he feels he will get his hospital. He is ever striving for narcotic legislation and was recently elected to a post for suffock County having to do with narcotics. 
The exact nature of the position was not learned. It was most difficult to get information; although the informant was most cordial, she was continually interrupted by phone calls or a busy office.

Due to the lack of having his patients with him under supervision, it is hard to know exactly what results can be stated as to how many persons stay "clean." He has probably treated 1500 patients. Mrs. Baird says that he thinks that $85 \%$ are "cured." She says he takes this figure from the fact that these persons have not been picked up by the police. She feels, this no proof, however, and much as she would like to hope that many are really off the drug would put the figure way, way down to only ten or fifteen persons whom she actually could vouch for as they come back to the meetings,etc., and keep in touch. This truely is quite a variance! But even if the doctor's figures are correct, he is the first to say, "Even this is not good enough!". He is a reformer and crusader and wants the hospital to extend what good he can do.

Although his offices are located in Spanish Harlem in a poor section, most of his clients come from better sections as of New Jersey and Long Islano and are from the "better families." 
Christian Reformed Church of Manhattan

Personnel and Program

The Christian Reformed Church of Manhattan, 2042 7 th Avenue, New York City operates a center for helping drug addicts. Rev. James Allen and Rev. Gordon Negan are in charge of its operation. This was a center the writer did not get to see as they had such a large group attending at the only time the writer could visit. For this reason she was discouraged from attending. Information was given by Rev. Allen on the telephone.

Rev. Allen is a former drug addict and opened this venture in 1957. Since then they have helped thousands. He feels that a thousand are cured a year, but was not specific as to how follow-up was made to be sure. Of those treated, however, the figure of $10 \%$ was given of those in treatment and those cured. Twenty to forty come per day.

The program is only a seven day plan and most of those in treatment only average coming five days. They must be detoxified before coming for help. The staff consists of the two ministers, a part time consulting psychologist, and $s \in v \in n$ ex-addicts. There is an overnight resident care. Treatment consists of counseling by the: staff talking with the group under treatment about their own experiences of how they were able to 
break the habit of drugs. Rev. Allen feels that his example as model also helps. Some persons come voluntarily and some are sent by the court. There is no screening. After this brief period of treatment they are sent to various half-way treatment centers. It was not learned where these might be, but as one man met at Hart Island, said he had come from treatment there, this is one possibility. This man, however, felt that he was not really helped at this church center. Hë felt the counseling too short a time. Rev. Allen also expressed the reason that more were not helped was that the persons did not stay with the treatment the full number of sessions. He would like to have more community rehabilitation centers as his which would mean the need for more money and personnel. He is not satisfied with his results. He said that the program did not emphasize a religious approach. The group's feeling is that the church helps the person, but it is more of a social sospel approach, rather than evangelical and soul-winning in nature.

\section{Teen Challenge}

History of Founding the Organization

In 1958 Rev. David Wilkerson, small town Assembly of God minister got his start in helping drug addicts. From seeing a Life magazine article regarding seven boys 
sentenced to jail for a murder, he went to New York City to see what could be done. And as Rev. Wilkerson explains, the publicity which was afforded him because the police would not allow him to see them in the court room, and he was bodily hoisted on their shoulders, made him idol to the gang boys. They accepted him and his message of salvation which he preached on the streets. These boys in turn told others. Some were heroin addicts. Later Rev. Wlikerson found an old house to remodel at 444 Glinton Avenue, Brooklyn and a start was made to keep drus addicts for a two week period. I The date the writer visited there were thirty boys and twelve girls. The average age of those helped is twenty-five.

After two weeks the boys are sent to a farm at Rehersburg, Pennsylvania and the girls to Garrison, New York for occupational rehabilitation and spiritual counsel with Bible classes. Here they stay on the average of six months. This information was received from Don. Wilkerson, director and brother of the founder, whom the writer interviewed on June 7 th, 1967. Approximately three thousand have been helped to date, it was learned, from Don Wilkerson.

IDavid Wilkerson, The Cross and the Swltchblade, Fleming H. Revill Co., Westwood, New Jersey, 1963, entire. 


\section{Effectiveness of the Program}

Twenty percent stay for six months and stay for advanced training. Of the $80 \%$ who left before the six months were up, $20 \%$ of those returned. So actually forty percent go through the program six months or more and $74.7 \%$ of that number are helped.

\section{Personnel}

They have a staff at the Clinton Avenue Teen Challenge of eight counselors, three ministers, the help of ex-addicts, and laymen and women. This is the first of now twenty such centers in the United States, Puerto Rico, and Canada. The twentieth, in Washington D.C. is just getting organized.

\section{Screening}

Rev. Don Wilkerson told the writer that before a person was accepted for Teen Challenge he was interviewed by the team of ministers and his motivation studied. If he just wanted to come in order to control the habit or cut cost, to forget about coming there for there was no real purpose. The organization makes them wait for three days then to test their sincerity before admittance to the center for treatment. One out of ten come back.

The first step in cure, says his brother, Rev. David Wilkerson, in A Positive cure for Drus Addiction, is to admit you are a junzie and hooked and losing 
your life and soul. Only those who want cure need come. When you admit you are hooked and there is no other way to help yourself, then you can go to the next step. 1

The second step, he says, is to "Quit looking for an easy way out." There is no hospital or drug which can help you permanently. They are reminded of the many times they have been to hospital or clinic and then right back to the needle again. No doctor, psychiatrist or hypnotist can cure you: A doctor can pacify you with some pills; a psychiatrist can tell you why you are an addict--but they cannot cure you! 2

"Seminars and group therapy programs do not produce lifelong cures--in spite of all the claims. Homes for addicts that practice seminar sessions cannot put in you what it takes to stay clean when you are on your own and in a real crisis:"3

"Cold turkey is the best and quickest way to start a cure. Cutting down on your supply with medication is just an excuse to dras out your habit. Cold turkey

$I_{\text {David Wilkerson, A Positive Cure for Drus Addiction, }}$ N.Y. Teen Challenge, 1963. p. 14-16.

2 Ibid.

3 Ibid. 
never killed anybody. It's that way in jail--it's the best." I

"You must quit smoking! No addict can be permanently cured until he is off cigarettes for good. If you can't quit your little habits--how are you going to quit your big habits. Fufural is a toxin in tobacco that will drive you back to your needle! What's the difference if you are addicted to tobacco or arugs-they are both habits of the mind! I dare anyone in the world to prove to me an addict is really cured if he is still smoking!"2

He goes on to say that it isn't to please someone else that the person should want cure, but that the person wants help himself. Nor can the person be cured in a few weeks. They are told to allow a years time and forget the job as they couldn't work anyway. Nor are they going to be babied, but must work for a cure. 3

Step three is the spiritual part. "Give yourself over to God! God is the only one who can cure you! Nothing is impossible with God. If anyone claims cures outside of the power of God, they are lying."

\footnotetext{
$1_{\text {Ibid. }}$

Ibid., p. 18-19.

3 Ibid.
} 
"You must come like a child, asking help, he tells them. God won't turn you down. You must believe the Bible has the secret to your cure." "You shall know the truth and the truth shall make you free," he quotes from the Bible. 1

More than just belief in God is needed--you must believe in Jesus Christ and confess Him as Savior. "He will make you into a new man. The old life will pass away and everything will become new!"2

"Open your heart to God even more than you would do to a psychiatrist and tell Him all about your problem. Then confess to Jesus all your sins and every bad thing you can remember you have done. Ask him to forgive your sins and to come into your heart. He will drive out the desire for drugs and give you power over it:" 3

Wilkerson further states, in this booklet, "Don't just think your prayers to God--talk out loud to Him. He understands you and knows all about your sins and your problems--but he wants you to talk to Him. While you are talking out loud to God you will suddenly know what prayer really is." 4

${ }^{I_{\text {Ibid }}}$.
${ }^{\text {Ibid }}$.
${ }^{{ }_{\text {Ib1d }}}$. 
"Talk to God," he says, "every day, at least five times. Read the Bible every day and fill your mind with thoughts from its verses. Keep asking for His helpeven if you have to do it a thousand times a day. He will never get tired of Iistening." I

"You must trust in God!--He never lets you down!" Step four is to start planning for life over again from the moment of surrender to God. "What do you want to do?", He asks. "What was your ambition before starting on drugs?", he suggests asking. Then start making plans. But now plans start with God. "Make Him a partner and don't ever let Him leave you by your neglect. Give God first chance to use your life. Maybe He will want you to help other addicts when you are fully cured."

He suggests never going back to old friends or hangouts even to see if you are cured as this is tempting God. Find new friends who are not addicts. 3

If you had no plans, he says, then jot down five things you think you would like to do or be. Spend a few weeks investigating these things and choose the one that appeals to you most. Choose a goal--you can never

I Ibia.

2 Ibid.

3 Ibid. 
again be a loafer or floater with no ambition. ${ }^{1}$ know what you want to do--then do after it! know what you want to do then go after 1t!--You can learn to love the things you once hated and learn to hate the things you once loved. You can do the right things now because God gives you power to do them. 2

Then he suggests as step five to turn your life over to God and you never have to fear again! "Don't be afraid you will go back on the needles! God guarantees a $100 \%$ cure. As long as you stay with God--He will stay with you. If you forsake God--you will go back." He further says not to fear your past as God forgives sins and forgets them. Nor should you fear that God will drop you or what people will say or think. When fears do come, pray about them, he suggests. Then he Gives a list of specific Bible verses which should be helpful. 3

The booklet is one which tells the type counseling an addict would get at Teen Challenge as well as being written in an enlarged tract form which might be read by an addict which might help him decide to accept Teen Challenge's help.

$1_{\text {Ib1d. }}$

IIbid., p. 19-23.

3 Ibid. 


\section{Religious Services Visited}

Religious services are held each morning at 10:30 except Sunday and Tuesday, Wednesday and Thursday evenings. The writer participated in a church service held the morning of June 7, 1967, and found an attractive chapel. The service was dignified; the testimony meeting was heartfelt. At the close of the Bible-centered preaching service an altar call was given which is an invitation to come to the fromt and pray regarding any need that a person might have. A lady, who is a minister and the minister who had given the message circulated themselves and in a warm accepting manner prayed with the various members of the group who had come to pray telling the minister his problem. They then laid a hand on each person and prayed for the person. Some became very enraptured and seemed caught into another world of the spirit and started speaking in what is known ag tongues. This is taught to be the experience of receiving the baptism of the Holy Ghost. The organist was playing rather loudly, but not offensively so, "Spirit of the Living God, Fall Afresh on Me." Whether those who were experiencing this speaking of tongues were doing it for the first time or were those to whom this experience was not new, it was not known. In all, the service was perfectly in order and nothing loud or jarring to the sensitivities. Perhaps the invitational music was rather loud so that persons praylng could tell their 
problems to only the minister without others hearing. At least, that is what happened. After the service the group quietly went out to lunch. Two services a day are held--one morning and one in the evening. Experiences of Youth Having Recelved the Bapt1sm of the Holy Spirit

In The Cross and the Switchblade, Rev. David Wilkerson tells of a twelve year old girl receiving the experience of receiving the baptism of the Holy spirit, saying she had used to drink a lot. Her mother brought her to the Center and she sat in the chapel and listened to all the other kids talk about how Jesus helped them when they were tempted. These drug addicts had problems, too, worse than mine. "We still get tempted," they would say, "but now we always mun into the chapel and pray." When they prayed, they spoke in another language but they looked happy and were sure of themselves. And when they got up from their knees, their temptation was gone. 1

So, she says, "they made me want the same thing. I went into the chapel one day to pray by myself. I started telling God all about my problems and asked Him to come into my life like He had to those drug addicts. Like a blinding light, Jesus burst into my heart. Something took

\footnotetext{
Iwilkerson, The Cross and the Switchblade, op. cit., p. 160 .
} 
over my speech. It made me feel like I was sitting down by a river that somehow was flowing through me and bubbled up out of me like a musical language. It was after this that one of the workers showed me in the Book of Acts what it was all about. It was the most wonderful thing that ever happened," says Neda. 1

Rev. David Wilkerson in the same book, further lets Joseph tell his story. "He (Jesus) helped me get rid of drugs. I used to take goof balls and marijuana, and I was beginning to sixin pop heroin. I already had the mind habit and I had to do this thing. When I heard about Jesus it kind of shocked me that He loved people in spite of all their sins. It stirred me when I heard that He puts real teeth behind His promises, by coming into us with this baptism of the Holy Spirit. The Holy Spirit is called the Comforter, they told me. When I thought of comfort I thought of a bottle of wine and half-a-dozen goff balls. But these guys were talking about comfort out of Heaven where I could feel clean later."

"So I got to wanting this just like Neda. In the chapel I cried to God for help, and that's when He came around. He took over my lips and tongue and I was speaking in a new language. At first I thought I was crazy, 
but all of a sudden I knew I couldn't be, because something was happening too. I wasn't lonely any more. I didn't want any more ärugs. I loved everybody. For the first time in my life I felt clean."I

On and on the kids talked of their experiences such as these Rev. Wilkerson stated in his book as they were explaining to a visitor. When the visitor, Father Gary, left, another happy experience came to another boy, Roberto, a sixteen-year-old who had been on heroin for two years and on marijuana before that. He had been in jail four times; one of these times was for stabbing another gang member in a street fight. The boy had not died, but Roberto feared someday he might kill: His parents, had stood by him, trying everywhere in vain to get help. Then he came to the center.2

Rev. Wilkerson explains how he found Roberto one day all fidgety which meant he wanted to get a "fix" or shot of heroin. After Rev. Wilkerson invited him to the service in the evening which would be preached by a former Mau Mau stret gang leader, Nicky would tell about the need of every drug addict to have the baptism of the Holy Spirit. Much to the surprise of the minister, Roberto did not get his fix, although he left the premises. He returned to the service where Nicky

\footnotetext{
I Ibid.

I Ibid., p. 63 .
} 
preached of the ten things the Holy Spirit would do for a person. "First of all you have power...then you're going to have a Comforter...next, you will have protection... you will have spiritual values... you will have life... you will be living with the Spirit of Truth...access to the Father will be yours... you will have hope and liberty. And how does all this come about? Through a dramatic, sudden, over-powering experience. Read about it for yourselves in Acts 10:44." When the boy finished his sermon his voice dropped and he spoke in almost a whisper. 'That's what is ahead of you in this new life. But tonight I don't think we want to read about it. And we don't want to talk about it. We want to do it. If you want this change and power and hope and freedom in your life, get to your feet and come up front. I'm going to lay my hands on your head just like st. Paul did and the same thing is soing to happen to you that happened to the new Christians in his time. You're going to receive the Holy Spirit.' I

"Roberto took one look at me and leaped to his feet; and my heort leaped with him"

"Roberto fairly ran to the front of the chapel. He grabbed Nick's hands and put them on his own head. Almost immediately the same thing happened to this boy

$1_{\text {Ibid. }}$ 
that had happened to my Grandfather; he began to tremble as if current were flowing through him. He fell to his knees, and the other boys stood around him, praying." I

"It was like reliving a scene from the Book of Acts. In less than two minutes a new language was flowing from Roberto's lips. It poured out like a spring bubbling up out of dry land. Of course, everyone was rejoicing. All the other drug addicts came around Nicky and Roberto and began saying, 'He's going to make it. He's coming through.' Nicky kept saying, 'Thank you, Lord. Thank you for helping these boys.'"2

"Then others picked it up saying 'Thank you, Lord, thank you for helping these boys. Than' you Thank you, Lord.'"3

Rev. David Wilkerson goes on to explain that the Holy Spirit did not always free a boy but trapped him. "This has been simultaneously one of the most discouraging and the most encouraging results of our work. At first our hopes were very high that the baptism would always, and permanently, free boys from the hold of heroin." 4

$1_{\text {Ibid. }}$.

I Ibid., p. 64. I Ibid., p. 64 4 Ibid. 
"There was good basis for our hope. As soon as we began to suspect that there was relationship between the baptism and a boy's ability to throw the habit, we made a special effort to lead our young dope addicts into the experience."

"At first we experienced, rather cautiously, on a marijuana user. Luis was one of our boys who had been smoking this weed, which addicts the mind but not the body. He received the baptism of the Holy Spirit, and his mind adaiction left him completely!"l

"Encouraged, we went on to a tougher assignment. What about a boy like Roberto, who had been on heroin, which addicts the mind and the body as well? What would happen to him now? We watched Roberto carefully for signs that he was back on the drugs, but day after day he came to the Center with his eyes shining and his hopes high. 'I think I'm on top of it, David. I have a tool I can use; I just come here with the other boys and pray." "12

\section{Other Boys}

"Time and again we got the same results. Harvey had been referred to us by the courts; he had been deeply addicted to heroin for three years, but after the baptism he said the temptation itself went away.

\section{${ }_{\text {Ibid. }}$ $2_{\text {Ibia. }}$}


Johnny had been on heroin four years, and pulled away successfully after his baptism. Lefty had used the needle two years, and after his baptism he not only stopped drugs, he decided to go into the ministry. Vincent used heroin two years, until his baptism, when he stopped instantaneously. Reuben had a fouryear addiction; at his baptism he was given the power to stop. Eddie had started on heroin when he was twelve years old; fifteen years later he was still using the drug, and was nearly dead from its continual use. The baptism of the Holy Spirit released him from his addiction."

"I was so excited that I checked with medical authorities to find out what grounds we had for making some bold claims. 'None,' I was told frankly. 'At Lexington, a boy is not considered cured until he has been off the stuff five years. How long have your boys been clean?"

"Not Iong."

"Just a few days?"

"On no, it's a matter of months. In a few cases over a year!"

"Well, that's encouraging. Tell me some more. I'd like to know about this baptism of yours." 2

${ }^{1}$ Ibid. 2 Ibid., p. 65 . 
"At the end of the interview I was warned again that a drug addict is virtually impossible to help, and that I should be on the lookout for a fall. 'And the sad part is,' I was told, 'when a boy slips, he goes back to a deeper addiction than before. If he was shooting twice, he'll go on three. If three, he'Il slip to five. 1 The degeneration is more rapid after a fa.11.'112

Ralph felt trapped by the Holy spirit. Even after the baptism of the Holy Spirit, he had not learned that Iiving in the spirit is as necessary as receiving the Spirit. 3

"RaIph had been on marijuana for two years and on heroin for three years. He was deep into the habit. He had tried a hundred times to break the addiction. He tried to leave his gang, where his buddies were mainlining with him. Each time he failed. There was only one out, Ralph thought: he had to take his own Iife before he took the Iife of someone else on a dark night when he was desperate for a fix. One night two years aso, Ralph climbed on a roof. He stood on the

$1_{\text {Ibid. }}$.

I Ib1a.

3 Ibid. 


\section{6}

ledge, ready to dive head first into the street. He was walting only until the sidewalk below him was clear."

"And at that moment, he heard the sound of singing."

"It came form one of our Gang Churches, méting in a building directly across the street from the tenement where Ralph stood. He lifted his head and listened. 'On a hill far away stood an old rugged cross...'"2

Wilkerson tells that the boy went insiae and again turned his life over to God and received the baptism of the Spirit. The boy has never been the same again. He went off using heroin for over a year. He left New York and went to live in California and was clean all that time, but returned to New York for a visit. The visit was in his old neighborhood where the boys taunted him about the needle. Wilkerson says, "We tried to keep in close touch with him, but Ralph was elusive." 3

"And then he fell. He made contact 4 and went up to his room and stuck the needle in his veins."

"Five times, before Ralph received the baptism of the Holy Spirit, he had tried to pull off drugs.

\footnotetext{
I I bid.

inid.

${ }^{3}$ Ibid., p. 166.
} 
Each time he was so disgusted with himself after falling that he started to drill more heavily than ever. Now he had been off over a year and drilling again."

"But a strange thing happened this time. The shot did not have its usual effect. The next day Ralph crept into the Center and asked for me. When he came into my office, he closed the door, and I guessed that he had been drilling." 2

"Something funn's happened, David," Ralph said, after he finally got courage to tell me what he had done. "After I got through drilling, it was like I hadn't had anything at all. It wasn't anything like I'd felt before. I felt something else, though. I suddenly had this strong urge to run to the nearest church and pray. And that's what I did. Davie, this time I was forgiven, and I didn't feel disgusted like before. Instead of going from bad to worse, the temptation just went away." 3

"Ralph's eyes shone as he said the next words. 'Do you know what I think? I think I'm trapped, all right. But not by heroin. I think I'm trapped by the Holy Spirit. He's in me and won't let me get away.'"14

\footnotetext{
${ }^{1}$ Ibid.

2 ibia.

3 ibia.

${ }^{4}$ Ibid.
} 
"Ralph: came back: to us humbly: and fully aware of the fact that the baptism had made him Christ's in a special way. He couldn't get away from Him even when he tried. The same thing was true of Roberto (a different Roberto, who had been drilling for fifteen years), who slipped for a short while but found he could not go back to the needle. And for sonny, who after he slipped once, came back with such fervor and such conviction that he wants to go to seminary." I

"Where does this leave us?" Power of the Holy Spirit Captures to Liberate

"Certainly we cannot claim a magical cure for dope addiction. The devil which hides in that needle is as deadly strong that any such claim would be folly. All we can say, perhaps, is that we have found a power which captures a boy more strongly than narcotics. But that power is the Holy spirit Himself, which unlike narcotics, does a strange thing for our boys: He captures only to liberate."2

"We are still in the infancy of what we consider a bold experiment. We have much to learn about what this religious experience can and cannot do in unhappy lives. Every day we are making new discoveries. Every

$1_{\text {Ibia. }}$

I ibid., p. 16, 17 . 
day we are making new discoveries. Every day we learn how to make our role more effective, how to increase our percentage of permanent cures."I

Physical Plant

The physical setting of Teen Challenge is very attractive. A large building has been built which houses chapel and dining hall on the first floor. In the basement are rooms set up for making tapes, the writer was told, but did not see. In the second floor are offices for the various staff as well as a large office where business correspondence is carried on. In another house, which was the original, are quarters for boys and staff who live with them. Down the street skipping a house or so is the residence which has been purchased for the girls. The writer was not given permission to see these private residences as it is here the addicts come and are having physical reactions from leaving the habit or "cold turkeying.". It is not something for the public to be shown as the therapeutic value would be lost of counselor with patient helping him have faith in God. There is a closeness of tie and a great caring.

It was explained that since all the staff was of one mind it put the addict in an environment conducive

\section{${ }^{I_{\text {Ibid. }}}$}


to spiritual structuring of all his activities. The writer did not notice any loud talking, but all seemed happy, but in a reverent serious attitude. Several girls and young men workers were setting out to meet boys and girls after the school let out. They would talk to them about Christ and of course, be learning if any needed the services of the center. The young people were radiantly happy and expectant. This they said was the result of their baptism of the Spirit. Initial Treatment

Treatment at the Clinton Avenue Center consists of reading scriptures to the person, singing hymns, praying with him, and encouraging the addict to pray for himself. They try to stay with him at all times. This is during the withdrawal period of a few days.: Then they get them to the services in the chapel and stress his needs of confessing his sin to God, so that God could forgive and help him start life over again.

Referrals come from the law and probation officers, 1 from the Damascus Christian ${ }^{2}$ Church who has no facilities for women, and word of mouth, street meetings and contacts as well as the contacts the group makes in Greenwich

\section{lDuncan, p. 112.}

2This was stated by Rev. Michael Rodriguez of Damascus Christian Church. 
Village at their Lost Coin evangelism (passing out cookies and talking of Christ in a store front bullding three nights a week).

\section{Sent to Training Camps}

After about two weeksthe addict is sent to his respective farm location, according to sex, thus getting him in a new environment. Here the men are taught Bible, language, agriculture, woodwork, music and other subjects. It is hoped, Rev. Don Wilkerson told the writer that more vocational subjects can be added, but they need more staff to do this. After six or eight months some are sent to Bible school or college for further study. A number have become ministers. Some come back to the city to obtain jobs while some continue with the organization, taking staff positions.

The women learn home economics and secretarial skills as well as Bible, language, music and regular school subjects. They similarly are placed--either for further schooling, staff positions, or in regular jobs, outside Teen Challenge.

"This is the best place for us; we are serving the Lord here!", says one boy speaking of his farm experience. "Sure beats the Harlem streets and I know the Lord is watching over me here, but I wasn't sure when I was in the city. It's rough here, but I made 16is: 
it." 1

Rev. David Wilkerson, throughout his book, The Cross and the Switchblade, continually made reference to how the work started on falth and how various individuals had felt impressed to give to keep it going. It is entirely a work of faith.

Damascus Christian Church

In the absence of Rev. Leone Rousseau, her nephew by marriage talked to the writer regarding their work which started in 1958. Her background had been Catholic and Ruerto Rican. She was converted and felt led by God to come to New York City. She started a little church and it was not until fifteen years later she was led to see that her work was to help the addicts. She is now in her late forties, but the men call her affectionately, "mommie." Her name was then Roselle and the work is still associated with that name, although her husband died and she remarried. Her present husband is a former heroin addict, Rev. Cedric Rousseau. He is known as "papa." The nephew, Rev. Michael Rodriguez explained his conversion, not from arugs, but from a gang leader and several times in jail. He is an alert, energetic young husky of twenty-six. Mr. Edward

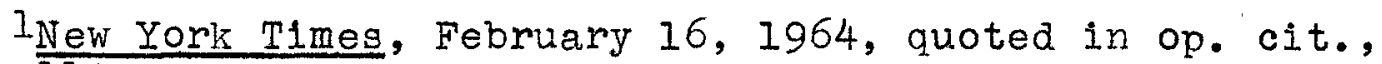
p. 112 . 
St. John, some ex-addicts who were not present as well as some volunteer ministers and a business manager who helped at times make up the group. Both Rousseaus were at their camp. It was not learned exactiy what was taught at camp or who was in charge. No one is paid a salary, but sifts of money, or in kind come in from interested individuals as the needs come. They feel satisfied in this way of faith as the only way. Men stay only $3-5$ days and then are taken to Mr. Dale, N.Y. staying three months to a year. It is hoped they stay a year. Women's problems are referred to Teen Challenge. Only once were women kept at the New York residence and church. Since both this group and Teen Challenge are Assemblies of God church groups they believe similarly and work closely with one another. The results of their work is similar as to percentages, it is felt, but records had been destroyed by water damage for this group and so they cannot keep up with all those helped perhaps, but say they get letters and find that most are living clean from drugs and clean from "sin" as upholding the standards of their church, Rev. Rodriguez said.

Their work is crowded into a narrow bullding Which looks like any other building on the block with steps inside to the several floors. On the first 
floor is the unpretentious church--nothing attractive as Teen Challenge has been able to build. On the next floor were Sunday School rooms where cots are placed or persons lie on the tables or floor. The upper floor is for the staff. Perhaps the kitchen and dining room were in the basement; it was not related. However, in the winter when men flock in to get off the roof tops and makeshift shelters they sometimes have seventyfive men a night. They even sleep on the cement basement floor and tables wherever found as in the dining room. The facilities of the staff and the whole bullding were very meager, but the same spiritual work is being done as Teen Challenge.

\section{Faith for New Building}

No addicts were present at the timeofithensit. This is typical, they sald, as the writerivisitednon July 8, 1967-80od weather, no raing butrome winter they flock in. Not all stay as some do not want the religious approach. The "cold turkey" method is used if not yet detoxified elsewhere.

Rev. Rodriguez said that they took any man who needed help and referred the women to Teen Challenge. Their men run older than at Teen Challenge with some men who have had a heroin drug habit of from sixteen to twenty-two years. But the same miracles happen as to the younger set at Teen Challenge. 
He likes to cite their first star, Rev. Joe Gegogas, who has a forty-five bed facility patterned after theirs on South 3rd Street, Brooklyn, New York.

Some men stay three months and as high as a year at the camp. But during the few days at the New York city address they are screened as for interest and motivation, so that it will be worthwhile to take them on to camp, the writer was told by Rev. Rodriguez. 


\section{6}

\section{Procedures}

\section{Interest Aroused}

The writer first got interested in the subject of heroin addiction at Christmas time 1966 when her daughter was writing a paper for a health class in school, regarding drus addiction. The writer picked up June, 1965 edition of Listen Magazine with the front cover, inside spread article, "Dr. With A Heart"! This article written by editor Francis Soper was the spark which set the writer on further inquiry. No adequate library was locally avaliable, so the writer made some after school trips to Chattanooga, Tennessee, twnty-five miles distant to do some magazine reading and learned of several places which treated heroin addicts. She wrote to Rev. Stephen Chinlund of Exodus House, but got no answer. The writer had already written once to Dr. William R. Baird, mentioned in the Listen article, but received no response. Five more letters followed and finally a response from his wife, Mrs. Adrian Baird. After the close of the school term the writer, who was teaching, but with a longer background of social work and free-lance writing as for Listen set out to New York. She checked with Elder Francis Soper, Editor of Listen regarding the questionnaire to be filled out upon the trip. He gave some helpful tips of how one got into New York. This was the writer's first trip 
since a teen-ager and driving with only a fourteen year old daughter was a bit awe-inspiring and fearful for the worst was told of New York and especially in the area in which the writer wanted to visit.

The writer arrived about noon Tuesday, June 7 , 1967 and went immediately to look up Dr. and Mrs. Baird. After a Iong wait, Mrs. Baird arrived. Office hours, it was learned were not until 2:00, but it was even later as he had had home calls to make.

The writer was informed that it would be impossible to speak with the doctor when he did arrive. He finally arrived and as the writer had her back turned, she only got a fleeting glimpse as she turned. However, when Mrs. Baird got a free moment, she called the writer to her desk and between phone calls the writer secured most of the information desired. Other questions came to mind after the interview. The writer had been told that Dr. Baird would not be having his usual Friday night session as reported by Elder soper, as he had a vims infection and would have to forgo it.

Upon return the next trip at exactly a month later the writer called again, after a letter had been unanswered, to see if the Friday night session would be help. The doctor was on vacation, but Mrs. Baird did answer some questions on the phone. The writer 
attempted to see her again at her office, but with parking difficulties was too late and the office had closed. Mrs. Baird promised to make a tape of a Friday night session, but so far has not.

On Wednesday, June 7, 1967, the writer went by subway to Teen Challenge and upon entrance at the gate met Don Wilkerson, manager of the New York facility. He answered some questions and invited the writer to visit the chapel service and then stay to lunch and he would answer questions on the questionnaire then. This he cordially did. The writer had heard from both him and his brother, Rev. David Wilkerson before coming to New York and had read, The Cross and the Switchblade and. Twelve Angels in Hell. The rest of the afternoon was spent asking questions of others and of taking advantage of all the New York phone books to call some places it was felt would be impossible to visit because of time and parking problems.

The writer called the Morris J. Bernstein Institute and talked to Miss Brandes at its location at Manhattan Hospital regarding their methodone program. She tried to talk with the Office of Coordination of Addiction Programs, but was unable to reach anyone who could give information.

On the third day, Thursday, June 8 the writer set out at 5:30 A.M. With her daughter to "head out of New 
York" or supposedly to do so to please her uncle with whom they stayed. He said it was totally impossible to park in Manhattan between certain streets and also it was impossible to try to do more than one thing in one day. So, the writer decided silence was the best policy and said her "goodnights and goodbyes" Wednesday night and slipped out early to do as she felt she must. With all the arguments against trying to go to Mianhattan and seeing Synanon, the writer could hardly phone for an appointment. They had no phone book of Manhattan either. So the writer set out and once away from the house asked directions to Manhattan from Long Island. Getting lost was a blessing as the writer happened to see two gentlemen going into e. lunch counter. who turned out to be plain clothesmen, officers of the Narcotics Bureau who told her she must visit Hart Island Community Center and that they might even hire her at $\$ 7,000$. (We went and the psychiatrist was interested in her as a social worker, but New York is New York!)

The writer got to synanon, or at least the address she had, but found it no longer in existence. They had rented a suite of rooms in a hotel, but had left some years ago. The writer consulted the phone book again and found another address Iisted, so as it was not so far and in a much better neighborhood was glad to get out of that parking place with a fourteen-year- 
oldrin the car: The new address is 35 Riverside Drive, a very lovely location and parking for one car around the corper! Parking can be difficult, but this happened to be the off day and parking was allowed. Otherwise, with towing costs $\$ 45$ to park illegally! As it was 8:00 A.M. the writer waited until 9:00 to visit. The manager was very busy, but finally agreed to answer questions.

Next we went to Hart Island Community Center and were greeted at the ferry by a graduate psychology student from a near-by college who did some volunteer work in leading a counseling group. He sald call should be made to get the "red carpet out!" Being a sort of prison situation whereby the ferry men took names when one went and when one left and the same applied when we got to the 1sland, the writer was happy when he volunteered to call. Dr. Jack Davis met the writer and sought to answer what questions he could as the facility had only been open three weeks. Dr. Davis then called the chaplain, Father Danlel Egan (known for his book, The Junkie Priest). He too was most cordial and showed the writer around and answered questions as well as explaining his counseling. He invited his visitors to lunch with the rest of the staff and the addicts being treated. Here was the first real invitation to mingle with adicts under treatment. He suggested she go 
finish lunch and sit beside them. Many things would have been interesting to know, but the writer felt it improper to be too nosy as she was not acting as social worker. However, later in the afternoon, one young man aid tell her of his "treatment" at another center, but as the writer had not yet been there, she hardly knew what to ask. In fact, it seemed like from the beginning of the whole interest in December, that it has been rather prodding in the dark, but maybe this is the whole feeling of everyone who has even been in the field a long time. These people look so normal, one doesn't think of them as different or of doing all the things reputed to them. The writer did not want to appear lgnorant, so perhaps silence was the best. Important officials

The writer was abain cautioned to call Daytop before coming. However, after getting a final handshake from Dr. Davis and back across the ferry, she learned that the Volkswagan which pulled off the ferry ahead. of her exit had contained Dr. Ramariz and others of his office. The writer had to wait a half hour before the ferry would return and then once across had to wait until the meeting was over. The addict who had spoken to the writer at lunch returned to tell of more places who treated addicts. 
When the meeting closed the writer got a view of Dr. Ramariz, but as he was busy, she spoke to Mr. Dominick M. DiGiora, Information Officer of the Office of Coordinator of Addiction Programs from Dr. Ramariz's office. He promised to send materials, which he did. On the ferry back the writer also visited with others who had attended the meeting. One man, whose name the writer failed to get was from the Westside Rehabilitation Center and Mr. White from the Rehabilitation Center at Manhattan Hospital. The writer fot questionnaires filled out, but due to really feeling she knew enough about the places only mentioned them in the study. She hoped to have time the second trip, but did not. Daytop

Five o'clock traffic rush found the writer going from the far north corner of the Bronx to the far south corner of Staten Island to Daytop. It was 56 miles, but fortunately with the help of the psychology student's directions and friendly drivers along the way, Daytop was reached before dark. But the writer's daughter was fearful we would not get out by dark, adn al though this was a much safer location, the route to the New Jersey Turnpike was not known. It was found to be very near, however. But this is why the writer kept writing information from $a$ substitute informer and was called down for it. 
All three places that day had said they had evening meetings on the week-end. Teen Challenge and Dr. Baird also had such meetings the writer hoped to see a month later, but alas! Second Trip to New York

Upon the second trip, the writer did not arrive until Thursday evening at $6: 00$ and finding the New York Center contented herself in staying at its meeting rather than trying to venture forth without escort. The daughter was not along, so a more centrally located place was welcome rather than Long Island. The writer mace a phone call to Mrs. Baird and learned her husband was away, so as this was to be 10:00 P.M. until 3 or $40^{\prime}$ clock in the morning, the writer was frankly relieved again, although knowing Mrs. Baird this time, it was felt maybe something could be worked out. Early Friday morning the writer called for an appointment to Exodus House, which with the East Harlem Protestant Parish were visited as they are close together. Neither. of the ministers at Exodus House had more than time for a smile and a handshake as they were then ready to go to their therapy groups unless she would be willing to wait for an hour. It was felt that the time could not be spared, so the writer got information from the secretary, who seemed to know the program well. A parish worker there at the East Harlem Protestant Parish 
informed the writer that Exodus House was now Incorporated on its own and that they did not work especially with addicts, but had been the parent organization for Exodus House. The writer interviewed her, however to learn their religious philosophy and it was found that it was mainly a social gospel which implied and as had Exodus House implied was their belief in implementing the gospel in the heart of Spanish Harlem, New York's densest drug center. The writer had difficulty finding both places and even near neighbors had no idea where they were.

From here the writer tried to visit Hunter college to see Professor Bernard Lander for whom Dr. R.R. Banks worked while in New York on a project with the Office of Vocational Rehabilitation out of Washington, D.C. But Hunter College had no parking place for blocks.. The writer drove around and around one way streets and gave up as it would make her late to a 1:00 appointment at far flung Daytop Village.

Dr. R.R. Banks who lives on the campus of Andrews University is a professor at Notre Dame University, but was sent on this project to interview addicts using the Minneasota Multi-phasic test to get information relative to the personality types of these men. However, the information is not permitted to be released. 
At Daytop the writer observed a Seminar group as mentioned. The writer had called Mrs. Baird several times to try to talk a minute between her calls and attempted a 9:00 visit but was delayed for parking problems.

On Saturday morning the writer drove by The Haven to see its location, learning the doctor who practices on 5th Avenue actually lives here in Spanish Harlem as he devotes his night hours to the work.

After a visit to a Spanish Seventh-day Adventist service the writer went home with a family who helped her find the Damascus Christian Church which address was not what she had. There was no phone. He helped to find it by asking around, which was much appreciated as the Spanish responded to him more than they would have to her. It was in a very bad neighborhood slumwise. Saturday night at nine o'clock the writer attended the Synanon open house and a much broader understanding came of the group. After the program and discussion when guests were free to ask questions, the writer left New York. 


\section{Analysis of Data}

It was learned that each group had its criteria for screening those accepted for treatment in one way or another to test the seriousness of intent. TeenChallenge and Damascus Christian Church also had the additional screening of whether the person would accept the rule of no smoking and that their approach would be religious. Teen-Challenge only took one in ten. It was not learned what the other groups actually did as far as numbers turned away.

\section{Voluntariness}

So far, most all the places visited accepted only on a voluntary basis; Hart Island Community. Center will soon be filling with those sent by the court. This seemed to be noted in the good attitude of those in treatment and willingness to cooperate. Teen-Challenge gets some legal referrals and of course Exodus House working with Green Island prison is an example of involuntary patients in a sense, although prisonees they were not forced to join the group. Exodus House does not like to set referrals from the Welfare Department and does not follow through on them as they want the 
man to come voluntarily.

Residence Probram

Exodus House, is planning a residence program for a short duration for its newer enroliees, but later the men will again live in the community. This is to be open in the fall of 1967. The Haven had no residence program, but is hoping to do so. The Christian Reformed Church has no residence program nor did the writer hear of any plans for such. Damascus Church has residence when addicts are avilable--which is more in bad weather, but their program in the country carries on with those who have entered the doors of the New York facility. They want a better situation in New.York. Most groups felt the "in residence" and the "therapeutic community" advantageous.

The average stay in the residence center varied from over-night at synanon to be shipped to one of California's Synanons to similar short stays for residents of Teen-Challenge and Damascus Christian Church to the up to three year stay at Hart Island Community Center, where it is really yet indefinate. Methodone

Methodone was only used in the hospitals cited, but none in the places used for this study. The attitude toward methodone was all very negative among those in charge of the places studied. Cyclanzocine 
was not used by any group cited in the study, but only at Metropolitan Hospital as mentioned. Most had not heard of it. Medications, Et.

Only Dr. Baird prescribed vitamins, hormones, and medicines he felt helpful as he was the only medical doctor heading a program. He as well as others who used medical services might prescribe medications for other ailments having nothing to do with adiction. Dr. Baird's special diet was described as just good "meat and "taters diet" by his wife with no coffee or tea.

Massage was given only at Daytop and then just when a person might need it in withorawal pains and was not really a part of treatment, but just a loving sesture by another addict to be helpful. Group Counseling

Counseling was given by all groups and described as direct of "very direct!" In Daytop and Synanon groups it was lead by other resident adicts or at other times not with a formal leader, but just as a leader emerged from the sroup, al though Daytop did form groups around the idea of having a more advanced resident in the group. All groups except Dr. Baird used ex-addicts for at least part of their counselors. 
Personnel Used

Ministers were a vital part of Teen-Challenge, Damascus Christian Church, Exodus House, Christian Reformed Church of Nanhattan, and for a time at Hart Island. Hart Island had a regular doctor as well as a psychiatrist. Daytop, Exodus House, and the Christian Reformed Church of Manhattan had a consulting psychiatrist. Exodus House was the only group using a sociologist. All Groups except perhaps Dr. Baird uses ex-addicts in various roles. Dr. Baird has volunteers and it was really not established that these persons might be exaddicts, or at least some of them. They only help with malling and perhaps some record keeping, it was understood.

Hart Island plans to employ a number of social workers; it is the only group who has such plans. TeenChallenge in their farm programs, Damascus Christian Church, Exodus House, and The Christian Reformea Church of Manhattan uses vocational personrel to direct their program in this area. Damascus Christian Church is the only group known, except Dr. Balrd whose workers are not paid. Damascus Christian Church is solely a faith work for its workers.

\section{Addicts Helped}

As to the numbers helped, this varied a great deal. one wondered at the statistics given as so many factors 
are involved and at what point persons helped are counted as most had early drop-outs. Some listed them to make casualties higher and figures lower as Synanon who claimed a hundred percent, but another person there only claimed fifty percent.

All were striving for better results, except Synanon--and if they count a hundred percent cure, it is no wonaer! But another person's figure was $50 \%$. All needed more money and personnel. Some needed larger buildings or facilities. The vocational programs had not been anticipated which were mentioned, but not Iisted on the questionnaire.

\section{Summary and Conclusions}

It might appear that the secular institutions have as good or better a record of "cured" patients than those who stress a conversion experience and the power of the Holy Spirit to give help to them. However, the writer felt that those in the secular institutions or settings were for ever looking within themselves to find the answer to their problem rather than looking to God. They were worried about guilt as noticed in the various conversations of feelings which were shared and which seemed so important to the thinking of such groups as Daytop and Synanon. However, they had no one to take away that guilt. They were not pointed to God as the answer as was so evident by the contrast 
in methods of Teen Challenge and The Damascus Christian Church with the secular as noted or even "church related institutions" as Exodus House, The East Harlem Protestant Parish and The Reformed Christian Church of Manhattan. The parent organization of Exodus House, The East Harlem Protestant Parish gave a wish that conversions might take place, but their objective as carried out by: its child, Exodus House seemed lacking.

While a "cure" may be noted by those who have been to secular institutions, they do not have the power within themselves to be sure of avoidance of temptation. of course, no: one is, for that matter, but at least the Christian has a promise of heavenly power. Mr. Kline at Synanon expressed the thought that he, although "cured", for several years and still an associate of Synanon was fearful to be around drugs least he slip. Helpful Book for Ministers

Tommy I. Duncan, in Understanding and Helping the Narcotic Addict, as already noted, has written the only helpful book seen by the writer which might help the Christian minister or counselor dealing with heroln addicts. He points out that addicts need to form relationships with other people even after conversion as this was a problem in the first place in their personality adjustment. Adiction is not because of low 
economic depressed areas, which does produce the most of the bulk of the addicts, but in the problems of the people who live in those areas or even in areas of better suburbia. He points out that the disruption of family Iife, wherever found with consequent anguish, despair, and conflict, represent one root of the problem. He makes the analogy of a sick plant whose disease will show in 1ts leaves. When a family is some way amiss the symptoms will usually show in the children. To help a careful examination of the whole situation is needed involving the families in treatment too as no doubt the addict will return to them, or at least have some ties. While the minister usually only counsels the individual he must look at the entire picture. I

"The problem of addiction is complex, requiring all the human skills avallable. It also takes the Holy Spirit, Who, given the best efforts of man, blesses them and uses them for His own purposes, namely, releasing the captives and healing the broken in spirit."2 The writer would have Iiked to have had the time,

${ }^{I_{\text {Duncan, }}}$ op. cit., p. 137

I ibid., p. 138 . 
or upon further visits to these places formerly visited to be able to see more of how treatment was carried on. Visiting other places would probably also bring out other helpful methods, but it is believed that this is a good sampling of what can be done. Adventist Questions "Tongues" as Evidences of the Holy Spirit

Adventists strongly question the "tongues" feature to the Assembly of God approach as seen in Teen Challenge and discussed with those at the Damascus Christian Church. However, I question why we are not doing something in New York or elsewhere which we can more easily accept doctrinally. Perhaps individual ministers who are working in high drug areas are working with addicts. It is hoped that this paper may be useful. 


\section{BIBLIOGRAPHY}

Books

Anslinger, Harry J. "Drug Addiction," Encyclopedia Britanica, Vol. II, 1960.

Ausubel, David P. "Controversial Issues in the Management of Drug Addiction: Legalization, Ambulatory Treatment, and the British System." O'Donnell, John A. and Ball, John C., ed., Narcotic Addiction, New York, Harper and Row, $1966^{\circ}$

Ausubel, David and Pearl: "Ego Development Among Segregated Negro Children" Education in Depressed Areas, Passow, Harry A., ed., New York, Bureau of Publications, Columbia University, 1963.

Bereiter, Carl, Engelmann Siegfried. Teaching Disadvantaged Children in the Pre-school, Institute of Research in Exceptional Children, University of Illinois, Urbana, Illinois, Englewood Cliffs, New Jersey, Prentice Hall, Inc., 1966.

Brown, Lieutenant, Thorvald T., The Enigma of Drus Addiction, Springfield, Illinois, Charles C. Thomas, 1963.

Chien, Isidor; Gerald, Donald L.; Lee, Robert S.; Rosenfield, Eva. The Road to H, New York, Basic Books, 1964.

Duncan, Tommy. Understanding and Helping the Narcotic Addict, Englewood Cliffs, New York, Prentice Hall, Inc., 1965 .

Erickson, E. Chilidhood and Society, New York, Norton, 1950.

Glasser, William, M.D. Reality Therapy, New York, Harper and Row, 1965.

Gordon, Edmund w; wilkerson, Doxey A. , Compensatory Education for, the Dissdiantaged, New York, College Entrance Board, 1966. 
Green, Mary Francis; Ryan, Orletta. The School Children, New York, Random Press, 1965.

Hickerson, Nathaniel Education for Alienation, New Jersey, Englewood Cliffs, Prentice Hall, Inc., 1966.

Johnson, Elmer Herbert: Crime, Correction and Society, Homewood Illino1s, Dorsey Press, 1964.

Lindesmith, Alfred R. Drug Addiction, Crime or Disease? Bloomington, Illinois, Indiana University Press, 1961.

O'Donnell, John A.; Ball, John C. Narcotic Addiction, New York, Harper and Row, 1966.

Reissman, Frank. The Culturally Deprived Child, New York, Harper and Brothers, 1962.

Wilkerson, David. The Cross and the Switchblade, Westwood, New Jersey, Fleming Revell Co., 1963.

\section{Periodicals}

Casriel, Daniel, M.D. "New Success in Cure of Narcotic Addicts, "The Physician's Panorama, October 1966.

Cressey, Donald R. "Changing Criminals: The Applieation of the Theory of Differential Association," American Journal of Sociology, LXI September, 1955.

ElIinger, Bernice. "The Genesis of Creativity" The Reading Teacher, Vol. 19, The Ethic, New.York, Daytop Village, Inc., Vol. 13.

Fort, J.P. "The Psychodynamics of Drug Addiction and Group Psycotherapy" V, April, 1955.

Gerard, D.L., and.Kornetsky, C. "Adolescent Opiate Addiction, A Study of Control and Addict Subjects." Psychiatric Quarterly, Vol. 29, 1955.

Kobler, John. "Britain's R.x. of Our Drug Adalcts," Saturday Evening Post, July 30, 1966.

- "No Way Out," Newsweek, October 10, 1966. 
Nyswander, Marie, Dr. New Yorker, July 3, 1965.

Rodo, S. "The Psychoanalysis of Pharacothymia" (DruE Addiction) Psychoanalytic Quarterly, 1933.

Strole, L. "Social Integration and Certain Corollaries; An Exploratory Study," American Sociological Review, 21, December 1956.

Shubin, Seymour, "Therapeutic Village," S.K. and F. Psychiatric Reporter, March-April, 1967.

Soper, Francis A. "Doctor With a Heart," Listen Masazine, June.1966, VoI. 19, No. 9.

Vaillant, George E., M.D. "Atwelve Year Follow-Up of New York Narcotic Addicts: The Relation of Treatment to Outcome." The American Journal of Psychiatry, Vol. 122, No. 7., Jan. 1966.

Yablonsky, Lewis. The New Republic, August 13, 1966.

Zimmering, P.; Toolan, J.; Safrin, R.; Wortis, S.B. "Heroin Addiction in Adolescent Boys" Journal of Nervous Mental Disorders, 114, 1951.

Zimmering, Robert. "Synanon, State Seek Same Goals," The San Diego Union, January 9, 1964.

\section{Pamphlets}

Public Health Service, P.H.S. World, U.S. Department of Health, Education, and Welfare, Vol. I, No. 4, April 1966, a reprint.

Wilkerson, David, A Positive Cure for Drug Addiction, New York, Teen Challenge, 1963.

Winslow, Walker. A Lesson From History, Los Angeles, 1962.

Bulletins

Knight, R. "The Dynamics and Treatment of Chronic Alcohol Addiction," Bulletin, Mennenger Clinic, 1937.

New York State Narcotic Addiction Control Commission, Chapter 192 of the Laws of 1966. mim. Albany, New York. 
Reports

"Drug Addiction Among Persons in Chicago;" A Report of a Study Conducted by the IIIinois Institute for Juvenile Research and the Chicago Project, October 1955.

\section{Unpublished. Sheet and Flyer}

Synanon Philosophy, mim. Synanon.

"Want to Know More About Narcotic Addiction and New York State's New Program?" Narcotic Addiction Control Commission, Albany, New York. 


\section{Questionnaire}

Yes No 1. Are patients screened before accepting them for treatment?

2. Do patients come voluntarily?

3. Are patients kept in residence?

4. What length of time in residence is considered sufficient for cure?

5. What is the average stay in residence?

6. Is methodone used in treatment?

7. Are vitamins sometimes prescribed?

8. Are hormones sometimes prescribed?

9. Are special diets sometimes prescribed?

10. Is massage sometimes given during "cold turkey?"

11. Is cyclanocine used? How estensive has been its use?

12. Is counseling given? Describe method briefly.

13. Is coungeling given by:

1. social worker _4. minister $\quad 7$. layman

2. doctor -5 . ex-addict

3. psychiatrist -6. other-who?

14. Number of years you have been working actively with addicts.

15. About how many adicts have you treated?

16. About how many do you consider cured?

17. Are you satisfied with your results?

18. What facilities personnel could enable you to be more effective, in your program?

19. If any other methods are used, what are they? 